\title{
Stratospheric dryness: model simulations and satellite observations
}

\author{
J. Lelieveld ${ }^{1}$, C. Brühl ${ }^{1}$, P. Jöckel ${ }^{1}$, B. Steil ${ }^{1}$, P. J. Crutzen ${ }^{1,2}$, H. Fischer ${ }^{1}$, M. A. Giorgetta ${ }^{3}$, P. Hoor ${ }^{1}$, \\ M. G. Lawrence ${ }^{1}$, R. Sausen ${ }^{4}$, and H. Tost ${ }^{1}$ \\ ${ }^{1}$ Max Planck Institute for Chemistry, J. J. Becherweg 27, 55128 Mainz, Germany \\ ${ }^{2}$ Scripps Institution of Oceanography, UCSD, La Jolla, CA 92093-0221, USA \\ ${ }^{3}$ Max Planck Institute for Meteorology, Bundesstrasse 53, 20146 Hamburg, Germany \\ ${ }^{4}$ DLR-Institut für Physik der Atmosphäre, Oberpfaffenhofen, 82234 Wessling, Germany
}

Received: 20 October 2006 - Published in Atmos. Chem. Phys. Discuss.: 14 November 2006

Revised: 19 February 2007 - Accepted: 22 February 2007 - Published: 27 February 2007

\begin{abstract}
The mechanisms responsible for the extreme dryness of the stratosphere have been debated for decades. A key difficulty has been the lack of comprehensive models which are able to reproduce the observations. Here we examine results from the coupled lower-middle atmosphere chemistry general circulation model ECHAM5/MESSy1 together with satellite observations. Our model results match observed temperatures in the tropical lower stratosphere and realistically represent the seasonal and inter-annual variability of water vapor. The model reproduces the very low water vapor mixing ratios (below 2 ppmv) periodically observed at the tropical tropopause near $100 \mathrm{hPa}$, as well as the characteristic tape recorder signal up to about $10 \mathrm{hPa}$, providing evidence that the dehydration mechanism is well-captured. Our results confirm that the entry of tropospheric air into the tropical stratosphere is forced by large-scale wave dynamics, whereas radiative cooling regionally decelerates upwelling and can even cause downwelling. Thin cirrus forms in the cold air above cumulonimbus clouds, and the associated sedimentation of ice particles between 100 and $200 \mathrm{hPa}$ reduces water mass fluxes by nearly two orders of magnitude compared to air mass fluxes. Transport into the stratosphere is supported by regional net radiative heating, to a large extent in the outer tropics. During summer very deep monsoon convection over Southeast Asia, centered over Tibet, moistens the stratosphere.
\end{abstract}

\section{Introduction}

Even though the stratosphere is very dry compared to the troposphere, water is central in radiative and chemical processes, including ozone depletion. In the energy budget of the lower stratosphere the emission of thermal infrared (IR)

Correspondence to: J. Lelieveld

(lelieveld@mpch-mainz.mpg.de) radiation, mostly by $\mathrm{H}_{2} \mathrm{O}$ and $\mathrm{CO}_{2}$, is a main cooling term (Mlynczak et al., 1999). Further, $\mathrm{H}_{2} \mathrm{O}$ chemistry is the primary source of hydroxyl $(\mathrm{OH})$ radicals, which initiate oxidation processes and destroy ozone (Solomon, 1999). Important oxidation reactions by $\mathrm{OH}$ include the release of ozone destroying halogen radicals from $\mathrm{HCl}$ and $\mathrm{HBr}$, and the conversion of $\mathrm{CH}_{4}$ into $\mathrm{CO}_{2}$ and $2 \mathrm{H}_{2} \mathrm{O}$. The latter reaction is an important source of water in the middle and upper stratosphere, whereas in the lower stratosphere transport from the troposphere is prevalent (Remsberg et al., 1996). Despite the stratospheric dryness, temperatures can be low enough for water to condense, for example, into polar stratospheric clouds. Heterogeneous reactions on these clouds and the sedimentation of ice particles play a key role in the formation of the ozone hole.

More than half a century ago Brewer (1949) explained the dryness of the stratosphere by the large-scale ascent of air across the tropical tropopause, acting as a "cold trap". Owing to the negative temperature lapse rate in the troposphere, and the high and consequently very cold tropical tropopause, the air is "freeze-dried" at stratospheric entry. Although this general concept has been corroborated since (e.g. Holton et al., 1995), the locations and actual mechanisms controlling the freeze-drying have been subject of debate for decades, spawned by the discovery of a water vapor minimum (hygropause) a few kilometers above the tropopause (Kley et al., 1979).

The cold trap concept implies that cirrus clouds develop near the tropical tropopause, and the moisture is removed by the gravitational settling (sedimentation) of ice particles. If this were a general feature, cirrus would occur ubiquitously throughout the tropics, which is not observed. Since the 1980s several theories have evolved to account for spatially confined dehydration. On the one hand, deep convective penetration (overshooting) and localized rapid updrafts were emphasized (Danielsen, 1982; Sherwood and Dessler, 2001). On the other hand, particular fountain regions were

Published by Copernicus GmbH on behalf of the European Geosciences Union. 
identified at the tropical tropopause where temperatures are very low so that the cirrus clouds can form during slow ascent (Newell and Gould-Stewart, 1981; Jensen et al., 2001).

Additional explanations have been pursued to reconcile the presence of deep convection below the tropopause and stratospheric dehydration aloft, for example, by assuming convective excitement of gravity waves that propagate upward, cool the air in the wave crests and thus generate ice clouds (Potter and Holton, 1995), or by assuming a combination of dehydration mechanisms (Vömel et al., 2002). Both the gradual upwelling and convective processes leave a distinct water vapor isotope ratio in the lower stratosphere, and measurements of hydrogen and oxygen isotopes in $\mathrm{H}_{2} \mathrm{O}$ have shown that to some extent both processes are involved (Webster and Heymsfield, 2003).

Satellite measurements from the early 1990s onward have greatly improved the time-height view of water vapor in the lower tropical stratosphere (Russell et al., 1993). Mote et al. (1996) have used these measurements to demonstrate the seasonal dependence of the freeze-drying effect, with coldest and driest tropopause conditions during boreal winter (December-March). They showed that the dehydration signal is carried deeper into the stratosphere up to about 10 $\mathrm{hPa}$, and dubbed this phenomenon the tropical tape recorder. The upward motion of the water vapor minimum in the tape recorder also explains the location of the hygropause (Kley et al., 2000).

More recently, trajectory studies based on meteorological analyses have elucidated the transport pathways through the tropical tropopause region during which the air masses are dehydrated (Bannister et al., 2004; Bonazzola and Haynes, 2004; Fueglistaler et al., 2004, 2005). It was shown that the upper troposphere over the western Pacific Ocean is a major ascent region, and that the upper level monsoon circulation plays an important role in the transport deeper into the stratosphere. Furthermore, stratospheric chemistry-climate models have been developed to simulate dynamical, radiative and chemical processes. Despite recent advancements, there is a large spread in simulated water vapor fields, including the representation of the tape recorder and the location of the hygropause (Eyring et al., 2006).

Here we present results of a new atmospheric chemistry general circulation model (AC-GCM) that describes the lower and middle atmosphere (Giorgetta et al., 2006; Jöckel et al., 2006). The global scale of the model precludes that we explicitly compute convection and cloud microphysical details. Nevertheless, we show that the model reproduces observed dynamical features and tracer distributions, including the tropical tape recorder.

In the next section we review some main aspects of stratospheric radiation and dynamics to provide a context for our AC-GCM simulation results and to understand the desiccation mechanism. This section may be skipped by readers who are familiar with the literature. Subsequently we present our model and the satellite data used, comparisons of the differ- ent datasets and their interpretation, and we address the role of features that are not resolved by our AC-GCM. Finally we summarize the processes that control the dryness of the stratosphere.

\section{Stratospheric dynamics and radiation}

The stratospheric circulation is driven by the following main influences. Firstly, the differential solar heating of the stratospheric ozone layer in the winter hemisphere, i.e. between high latitudes in polar night and sunlit latitudes, causes large meridional temperature differences and hence a poleward pressure gradient. The additional effect of the Coriolis force on the rotating Earth generates the westerly circumpolar flow in the extra-tropics, giving rise to the observed polar vortices.

Secondly, extra-tropical wave disturbances, excited in the troposphere by land-sea contrasts, flow over mountains and synoptic weather systems, can propagate into the stratosphere when the flow is westerly, and exert a drag force onto the circumpolar westerlies. This deceleration of the polar vortex alters the balance between the pressure gradient and Coriolis effects, which induces a residual meridional circulation towards the winter pole and a sinking motion in high latitude winter (Haynes et al., 1991). Differences in the land-sea distribution and orography cause stronger wintertime wave effects on the stratospheric vortex in the Northern Hemisphere (NH) than in the Southern Hemisphere (SH).

The stratospheric mass balance is maintained by ascent near the equator, analogous to a fluid-dynamical suction pump drawing air upward and poleward from the tropical tropopause at about $100 \mathrm{hPa}(\sim 16 \mathrm{~km}$ altitude) (Holton et al., 1995). In the tropical middle and upper stratosphere the upwelling is augmented by solar short-wave radiative heating (via $\mathrm{O}_{3}$ ) although this is partly balanced through IR cooling by $\mathrm{CO}_{2}$ and $\mathrm{O}_{3}$ (Mlynczak et al., 1999). In the tropical lower stratosphere IR cooling by $\mathrm{H}_{2} \mathrm{O}$ is counteracted by IR heating by $\mathrm{O}_{3}$, and on average net heating/cooling rates are small (Gettelman et al., 2004a), generally less than $1 \mathrm{~K} /$ day. The IR radiative effects of $\mathrm{O}_{3}$ and $\mathrm{H}_{2} \mathrm{O}$ have a pronounced spatial distribution (Highwood and Hoskins, 1998; Norton, 2001), and our model results presented below show that regional differences substantially influence troposphere-to-stratosphere transport.

It is important to distinguish a transition region between the tropical troposphere and stratosphere between about 12 and $18 \mathrm{~km}$ altitude (i.e. about 200 and $75 \mathrm{hPa}$ ), called the tropical tropopause layer (TTL) (Highwood and Hoskins, 1998; Folkins et al., 1999). It has been proposed to define the TTL more accurately in terms of net radiative heating, but we argue against it because both the sign and the magnitude of this term vary strongly with the presence of cumulonimbus anvils and cirrus clouds. The latter can be found throughout the depth of the TTL (Wylie and Wang, 
1997; Dessler et al., 2006) and have a substantial impact on the heating profile (Hartmann et al., 2001; Corti et al., 2006).

By and large, upward motion below the TTL is governed by cumulonimbus convection, whereas above the TTL it is controlled by the large-scale dynamics. Thus both for the troposphere and the stratosphere the relevant process understanding is relatively well established, whereas for the TTL the picture is more ambiguous. This partly results from the fact that vertical velocities in the TTL are small and difficult to measure, especially above extensive cumulonimbus anvils. Furthermore, it is clear that the initial impact of cumulonimbus convection is moistening because these clouds carry saturated air and condensates into the upper troposphere and TTL (Soden, 2004; Luo and Rossow, 2004, Gettelman et al., 2006a). Therefore, an explanation of stratospheric dryness will need to reconcile the direct moistening and indirect dehydration attributes of convection.

The coldest parts of the TTL are found over the areas with most extensive deep convection, notably over the western Pacific Ocean warm pool (Seidel et al. 2001). In these cold regions thin cirrus clouds can be formed, also known as subvisual or subvisible cirrus (Wylie and Wang, 1997). These ice clouds can desiccate the air by ice particle sedimentation (Jensen et al., 2001), and our model results presented below show that this process is most efficient between 200 and $100 \mathrm{hPa}$.

Here we focus on the geographic region where upward motion predominates in the lower stratosphere, between $30^{\circ} \mathrm{N}$ and $30^{\circ} \mathrm{S}$ latitude (Rosenlof, 1995). We consider the ten year period 1996-2005 for which model calculations have been performed and satellite data are available. The pressure altitudes on which we concentrate our model evaluation are $\sim 100 \mathrm{hPa}$, approximately representing the traditional climatological tropopause in the middle of the TTL, and $70-75 \mathrm{hPa}$, near the top of the TTL where dehydrated air enters into the stratosphere.

\section{Numerical model}

The atmospheric chemistry GCM used in our study couples the 5th generation European Centre - Hamburg model, ECHAM5 (version 5.3.01) (Roeckner et al., 2003, 2006) to the 1st Modular Earth Submodel System, MESSy1. This model - abbreviated E5M1 - includes a comprehensive representation of tropospheric and stratospheric cloud, radiation, multiphase chemistry and emission-deposition processes (Jöckel et al., 2006). The model has a spectral dynamical core, computing the atmospheric dynamics up to wave number 42 using a triangular truncation (T42), while physical and chemical parameterizations are calculated on the associated quadratic Gaussian grid at a resolution of about $2.8^{\circ}$ in latitude and longitude (Roeckner et al., 2006).

The vertical grid used here resolves the lower and middle atmosphere with 90 vertical layers from the surface to a top layer centered at $0.01 \mathrm{hPa}(\sim 80 \mathrm{~km}$ altitude $)$. The mean layer thickness in the lower and middle stratosphere is about $700 \mathrm{~m}$, sufficient to resolve vertically propagating waves with vertical wavelengths of $2.8 \mathrm{~km}$ and longer, which is a prerequisite to realistically simulate the quasi-biennial oscillation (QBO) (Giorgetta et al., 2006). In the tropopause region the vertical resolution is even higher, about $500 \mathrm{~m}(6-10 \mathrm{hPa})$.

Prognostic variables, predicted on the basis of fundamental (primitive) equations in spectral space, i.e. temperature, divergence, vorticity, (the logarithm of) surface pressure, and those in grid point space such as specific humidity, cloud liquid and ice water and chemical tracers, are calculated every $15 \mathrm{~min}$ (at T42 resolution). Orographic and non-orographic gravity waves are parameterized in ECHAM5 (Manzini et al., 2006, and references therein). A similar setup of the non-orographic gravity wave parameterization was used in Manzini et al. (2003) and Steil et al. (2003). Details of the model setup are provided in Jöckel et al. (2006); note that we use the S2 model setup described in that article.

ECHAM5 has been coupled with MESSy1, which comprises a modular interface structure that connects submodels to the dynamical core model (Jöckel et al., 2005; see also www.messy-interface.org). The tracer advection is calculated with a mass conserving flux form semi-Lagrangian scheme (Lin and Rood, 1996). The ECHAM5 radiation scheme distinguishes four UV-VIS and near-IR, and 16 thermal IR spectral regions (Wild and Roeckner, 2006), and it utilizes the online computed tracer distributions. Photolysis rate calculations for the troposphere up to the mesosphere are based on the eight spectral band approach described in Landgraf and Crutzen (1998), considering absorption and scattering by gases, aerosols and clouds in a delta-two-stream method.

Detailed chemistry calculations are performed using a kinetic preprocessor (Sandu and Sander, 2006), applying a Rosenbrock solver, to describe a set of 177 gas phase, 57 photo-dissociation and 81 heterogeneous tropospheric and stratospheric reactions (Sander et al., 2005). Details of the chemical mechanism (including reaction rate coefficients and references) can be found in the electronic supplement of Jöckel et al. (2006) (http://www.atmos-chem-phys-discuss. net/6/1/2006/acpd-6-1-2006-supplement.zip).

For the representation of natural and anthropogenic emissions and dry deposition of trace species, including micrometeorological and atmosphere-biosphere interactions, wet deposition by large-scale and convective clouds, multiphase chemistry and polar stratospheric clouds, we refer to the detailed descriptions by Ganzeveld et al. (2006), Kerkweg et al. (2006a,b) and Tost et al. (2006a,b). The results of the tropospheric and stratospheric chemistry calculations, using a number of diagnostic model routines, have been tested against in situ and satellite measurements (Jöckel et al., 2006).

Cloud convection is described using the method presented in Tiedke (1989), which assumes that an ensemble of clouds 
modifies the large-scale environmental dry static energy and specific humidity. The scheme distinguishes three types of convection (Roeckner et al., 2003): i) Penetrative, deep convection, triggered by moisture convergence exceeding evaporation, in which entrainment is proportional to the large-scale moisture convergence; ii) Shallow convection, mostly triggered by subcloud layer turbulence; and iii) Midlevel convection originating at higher altitudes, e.g. frontal clouds in extra-tropical cyclones, where the cloud base and entrainment are determined by the large-scale flow.

An addition to the convection routine by Nordeng (1994) accounts for organized entrainment/detrainment in deep convection, and mass closure based on convective available potential energy. An intercomparison of different convection schemes in ECHAM5 has shown that the present model setup produces a realistic hydrological cycle, including clouds, precipitation and water vapor distribution in the upper troposphere and lower stratosphere (Tost et al., 2006b). The convective tracer transport calculations use a monotonic, positive definite and mass conserving algorithm following a bulk approach (Lawrence and Rasch, 2005; Tost, 2006).

The model scheme for stratiform clouds includes prognostic equations for liquid and ice water and for the higher order moments of total cloud water (Roeckner et al., 2003). The description of cloud physics includes rain formation by coalescence, the aggregation of ice crystals into snowflakes, accretion of cloud droplets by falling snow, gravitational settling of hydrometeors and phase transition processes (Lohmann and Roeckner, 1996). Between $238 \mathrm{~K}$ and $273 \mathrm{~K}$ a mixed cloud phase is assumed, whereas at lower temperatures the condensed water is only in the form of ice.

The parameterizations of cloud processes are relatively detailed for a GCM, and include condensation/evaporation of liquid water, deposition/sublimation of ice, evaporation of rain, sublimation of snow, autoconversion of cloud droplets, accretion of cloud droplets by precipitation, homogeneous, stochastical-heterogeneous and contact freezing of droplets, and aggregation of ice crystals and melting of cloud ice (Lohmann and Roeckner, 1996). Nevertheless, the cloud parameterizations only account for cloud bulk properties, not for microphysical details such as droplet and crystal number concentrations. A description of the ECHAM5 simulated hydrological cycle is presented in Hagemann et al. (2006).

The growth of ice crystals below temperatures of $238 \mathrm{~K}$ takes place by the deposition of water vapor. At temperatures above $238 \mathrm{~K}$ water vapor deposition only takes place if cloud ice is already present. The size distribution of ice crystals is based on an empirical relationship between the effective particle radius of the ice crystal distribution and the ice water content derived from aircraft observations. The sedimentation of ice particles is also parameterized through an empirical description, representing observed ice mass precipitation rates (Heymsfield and Donner, 1990). The model calculated mean ice water content of cirrus clouds over the equatorial Pacific Ocean compare well with ice measurements in the
205-270 K temperature interval (Lohmann et al., 1995; McFarquhar and Heymsfield, 1996).

In order to analyze the transport fluxes of air and water in its different phases, we apply the ATTILA Lagrangian transport scheme (Reithmeier and Sausen, 2002), for which the model atmosphere is subdivided into about 1700000 air parcels of constant mass (ATTILA: Atmospheric Tracer Transport In a Lagrangian model). The scheme applies a fourth order Runge-Kutta method for advection, and we employ it diagnostically as an on-line forward trajectory model. The results of this method have been tested against a trajectory model using data of the European Centre for Mediumrange Weather Forecasts (ECMWF) (Stohl and Trickl, 1999; Traub, 2004).

The online coupling of the ATTILA transport scheme into our AC-GCM prevents time interpolation errors typical for trajectory models, and it is fully mass conserving. Each of the computed forward trajectories has a "clock" to determine the moment at which a certain boundary is surpassed. The selected boundaries are the 200, 100 and $75 \mathrm{hPa}$ pressure levels in our AC-GCM. Since two-way transport can occur over such boundaries, we apply a residence time criterion of $96 \mathrm{~h}$ to define an exchange event as "almost irreversible" (Wernli and Bourqui, 2002). In addition, we performed these calculations across isentropic surfaces, i.e. the potential temperature levels 340,380 and $420 \mathrm{~K}$, roughly compatible with the above pressure levels.

\section{Model nudging}

GCMs can be applied to simulate atmospheric conditions over extended periods, and the results of such simulations can be statistically compared with climatologies based on long-term observations or to other model simulations. For atmospheric chemistry and stratospheric water vapor computations this is more difficult because extended data sets are rare, and it is more challenging to apply statistical techniques in model evaluation. Therefore, we follow the strategy of nudging the model toward realistic meteorological conditions, so that an evaluation of model results against observations is less dependent on the size of the datasets and a direct comparison becomes more meaningful.

In addition to prescribed sea surface temperatures, the model has been nudged towards realistic meteorological conditions for the period 1996-2005, based on ECMWF operational analyses, by adding a Newtonian relaxation term to the four above mentioned prognostic variables in spectral space, i.e. vorticity, divergence, temperature and surface pressure (Van Aalst et al., 2004). Several precautions prevent the excitement of spurious waves. Firstly, the ECMWF data are projected onto the model levels and surface orography by a interpolation procedure developed by I. Kirchner, Free University of Berlin (personal communication), based on the method described in Majewski (1985). Secondly, the 


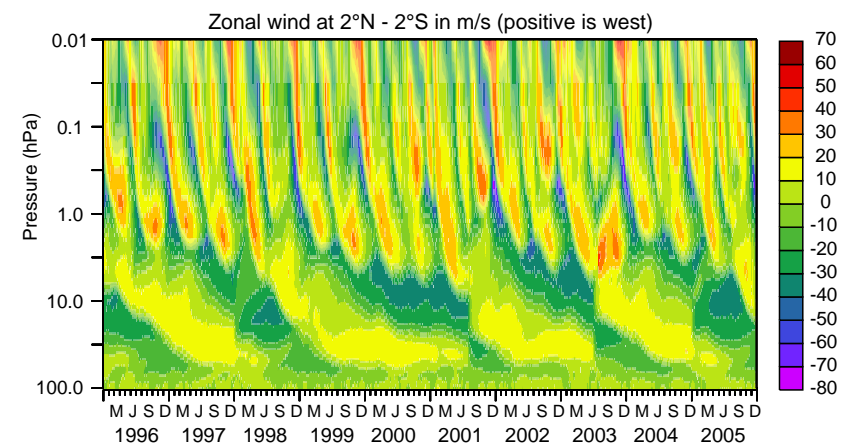

Fig. 1a. Model calculated equatorial wind, showing the SAO in the mesosphere and upper stratosphere and the QBO in the middle and lower stratosphere.

nudging strengths are very low (about $10^{-5} \mathrm{~s}^{-1}$ ), with a $6 \mathrm{~h}$ relaxation e-folding time for vorticity, $24 \mathrm{~h}$ for temperature and surface pressure and $48 \mathrm{~h}$ for divergence. Thirdly, a slownormal-mode filter is applied to the nudging data, which removes the fast components (Daley, 1991).

Finally, we avoid inconsistencies between the ECHAM5 and the ECMWF boundary layer representations by leaving the lowest three model levels free (apart from surface pressure), while the nudging increases stepwise in four levels up to about $706 \mathrm{hPa}$. The nudging tapers off to zero at $204 \mathrm{hPa}$ to allow unconstrained simulations of the TTL and stratosphere. From the perspective of the present study, the T42/2. $8^{\circ}$ and 90 layer resolution of the model is sufficiently high for the TTL and upward, though relatively low for the troposphere. The latter limitation is made up for by nudging the tropospheric part of the model using ECMWF data, which have been computed at much higher resolution.

We emphasize that it is important not to nudge the parameters and processes that directly control water vapor and chemical tracers, and only optimize boundary conditions for the model-data comparison. Since the nudging is weak, the model reproduces the actual meteorology approximately but not exactly, so we still need to rely on some statistical comparison with measurement data. Below we will compare probability density functions from model output and satellite measurements of stratospheric water vapor.

Figure 1 presents the results of the 10-year E5M1 simulation used in the present study, showing that the model realistically simulates the Semi-Annual Oscillation (SAO), the $\mathrm{QBO}$ and the stratospheric tape recorder. A comparison with measured tropical wind reversals in the QBO is presented by Jöckel et al. (2006) for a coupled atmospheric-GCM simulation, by Giorgetta et al. (2006) for a model version without chemistry, and additional evaluation against satellite observations is presented below. These simulation results are available on request (http://airdata.mpch-mainz.mpg.de).

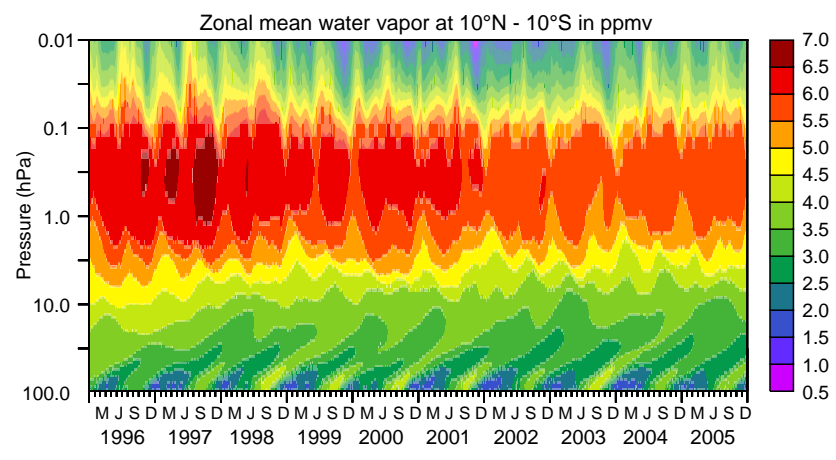

Fig. 1b. Water vapor in the tropical middle atmosphere and the characteristic tape recorder signal, discernable for about 1.5 years after entrance into the stratosphere at about $100 \mathrm{hPa}$.

\section{Satellite data}

A long time series of stratospheric water vapor measurements is available from the Halogen Occultation Experiment (HALOE) on the Upper Atmospheric Research Satellite (UARS) (Russell et al., 1993). The instrument operated from the fall of 1991 until November 2005, thus providing an extensive data set to compare with our model simulations for the 1996-2005 time period. The comparison between model and satellite data focuses on 1997-2005, thus omitting 1996, because the first year is too close to the initial conditions of the model, which were based on HALOE data over the five years prior to the simulation period.

HALOE was a solar occultation limb sounder operating in the near-IR during sunrise and sunset; water vapor was measured in the $6.6 \mu \mathrm{m}$ channel. An advantage of solar occultation instruments is that a relative measurement is performed, i.e. the ratio between solar radiation outside the atmosphere and that minus atmospheric attenuation. This technique may be conceived as self-calibrating and suffers little from instrument drifts, which is particularly useful for long-term observations. HALOE provided global coverage in the stratosphere and mesosphere at a vertical resolution of about $2 \mathrm{~km}$, with a total accuracy within about $\pm 10 \%$ over much of the height range and decreasing to $\pm 30 \%$ near the tropopause (Harries et al., 1996). A disadvantage of HALOE was that the number of measured profiles was relatively small, and global coverage was only achieved within about a month. Secondly, we use data from the Michelson Interferometer for Passive Atmospheric Sounding (MIPAS) on the European Environmental Satellite (ENVISAT). MIPAS is a high-resolution Fourier transform spectrometer, a limb scanning sounder operating in the near- and mid-IR, i.e. 4.15-14.6 $\mu \mathrm{m}$ (Fischer and Oelhaf, 1996). The instrument has been operational since the summer of 2002, and provides global coverage with $14-15$ orbits per day at a horizontal resolution of $300-500 \mathrm{~km}$ and a vertical resolution of about $3 \mathrm{~km}$. Here we use MIPAS temperature data for the period 


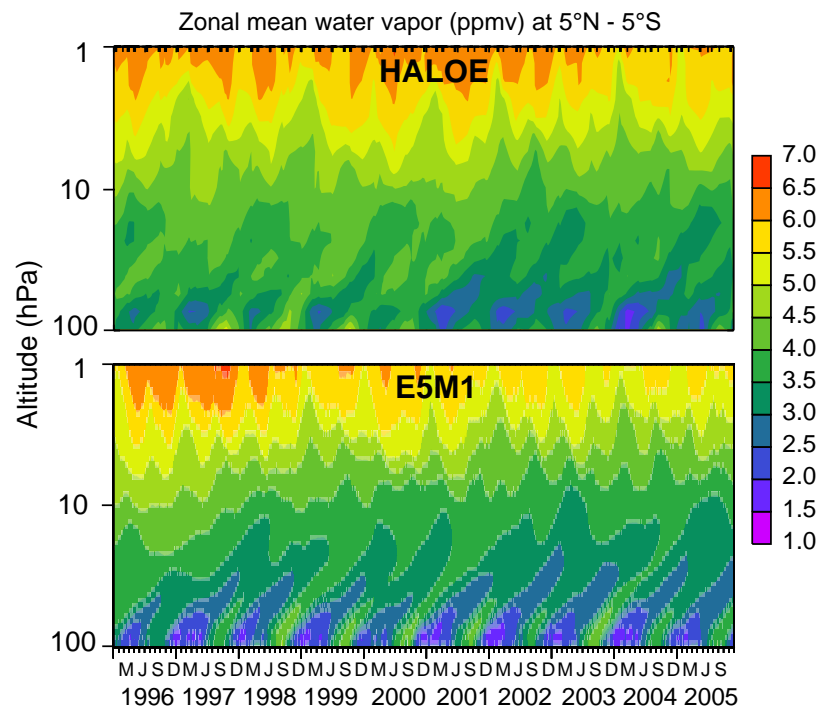

Fig. 2. Zonal mean water vapor from HALOE satellite measurements and E5M1 model calculations. The tick marks at the upper bar indicate the points in time of the measurements. Note that HALOE measurements in the tropics are largely limited between about $5^{\circ} \mathrm{N}$ and $5^{\circ} \mathrm{S}$ latitude.

December 2002-November 2003. The potential bias of temperature measurements in the $10-35 \mathrm{~km}$ height interval has been assessed to be smaller than $0.5 \mathrm{~K}$ (Wang et al., 2005), with a total accuracy of individual data points (given as the square root of the quadratic sum of random and systematic errors) of $0.5-1.5 \mathrm{~K}$. Finally, we use data from the Atmospheric Infrared Sounder (AIRS) on the NASA Aqua satellite (Aumann et al., 2006). This is a nadir scanning grating-array spectrometer, which measures in the 3.7-15.4 $\mu \mathrm{m}$ spectral region in $>2000$ spectral channels at a horizontal resolution of $50 \mathrm{~km}$ and a vertical resolution of $1-2 \mathrm{~km}$ from the surface up to the lower stratosphere. The instrument is operational since summer 2002. A comparison of AIRS temperature data with balloon sounding and in situ aircraft measurements in the upper troposphere and lower stratosphere indicates a total accuracy within $\pm 1.5 \mathrm{~K}$ near the tropopause (Gettelman et al., 2004b; Divakarla et al., 2006).

\section{Results and discussion}

\subsection{Middle and upper stratosphere}

Figure 1 shows the model calculated zonal wind in the equatorial stratosphere (top) and zonal mean water vapor concentrations between $10^{\circ} \mathrm{N}$ and $10^{\circ} \mathrm{S}$ latitude (bottom). The computed water vapor mixing ratios compare favorably with HALOE measurements, although the modeled amplitude of the seasonal cycle seems somewhat stronger (Fig. 2), as discussed in more detail in subsequent sections. Since the dif- ference between the model and HALOE data is similar to the total accuracy of the satellite measurements and data retrieval, it seems reasonable to qualify this as good agreement.

In earlier work it has been discussed that the signal of the QBO can be identified in tracer distributions, including ozone and water vapor (Randel et al., 1996; Giorgetta and Bengtsson, 1999; Geller et al., 2002). The QBO modulates the upward velocity of air in the tropical stratosphere, and the temperature signal can modify the specific humidity. Therefore, the accurate simulation of the QBO is required to realistically compute the tape recorder signal in water vapor (Giorgetta et al., 2006). Nevertheless, by comparing Figs. 1a and $b$ the role of the QBO in the water vapor distribution is not clearly evident.

Closer inspection reveals that during the easterly phase at about $10 \mathrm{hPa}$ the dry tongues reach to somewhat higher altitudes than during the westerly phase. In an earlier model version the upward penetration of moist air seemed deeper during the easterly phase (Giorgetta and Bengtsson, 1999). However, in this earlier work the oxidation of methane was not considered, and it appears that during the westerly phase methane derived moisture has an increasingly stronger downward influence than in the easterly phase, which counteracts the QBO modulation of water vapor from below.

Interestingly, a rather strong influence is manifest from the $\mathrm{SAO}$, where the westerly phase coincides with the most humid conditions. From our model results we identify relatively narrow water vapor troughs in January and July and somewhat wider peaks in April and October in the upper stratosphere, possibly a few weeks earlier than seen in satellite data during the period 1992-1995 (Jackson et al., 1998). The troughs are strongest in boreal winter, and they seem to progress downward with a few $\mathrm{hPa} /$ month. This effect may include a meridional advection component that gives rise to anomalies that wax and wane in winter and summer, respectively. It is also interesting to note in Fig. 1a that the westerly phase of the QBO starts after the westerly phase of the SAO has progressively reached lower altitudes in the stratosphere, suggestive of a causal relationship between the SAO and QBO.

In the upper stratosphere there is a clear relationship between dryness and the easterly phase of the SAO, during which tropical dehydrated air is transported upward more efficiently. The relatively large interannual variability in the easterly phase coincides with relatively large variability in water vapor, whereby the lowest water vapor mixing ratios occur during the strongest easterlies, which relates to the strength of the planetary wave forcing. Conversely, during the downward propagation of the westerly phase below the westerly jet upward transport of dry air is reduced.

\subsection{Lower stratosphere}

Although the long time-span of the HALOE data series is unique, for the lower tropical stratosphere the comparison 


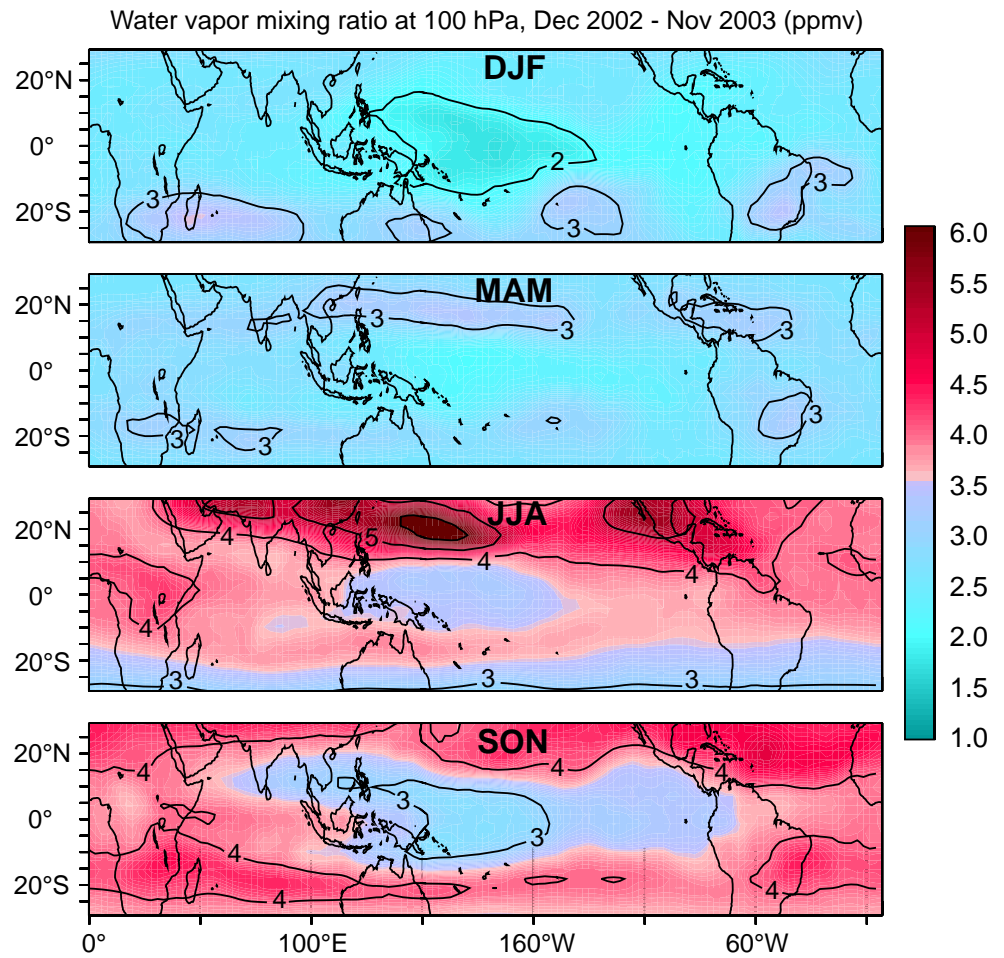

Fig. 3. Model calculated water vapor (ppmv) during four seasons at the model level nearest to $100 \mathrm{hPa}(97 \mathrm{hPa})$ for the period December 2002 to November 2003 .

between modeled and measured water vapor is hampered by the sparseness of satellite observations, especially near $100 \mathrm{hPa}$. The HALOE water vapor retrieval is affected by thin cirrus cloud "contamination", and since these clouds occur in very cold regions of active dehydration, as discussed in the next section, it is conceivable that the data are biased. Furthermore, by interpolating sparse HALOE data to display long-term tendencies, as shown in Fig. 2, the variability and seasonal cycle of water vapor, being particularly strong near $100 \mathrm{hPa}$, are suppressed. The limited number of profiles from which Fig. 2 (top panel) is constructed is indicated at the upper bar, whereby many of these profiles do not reach down to $100 \mathrm{hPa}$.

To circumvent these problems, we performed a direct point-to-point comparison between both data sets by sampling the model results (from 5 hourly output) as closely as possible to the location and time periods of the HALOE measurements. We reiterate that we cannot expect that the applied nudging procedure leads to an exact mimicking of the synoptic variability, and we must also accept sampling errors related to the different resolutions of the data sets. Note the vertical resolution of HALOE is coarser than the model, and the averaging kernel of the HALOE data retrieval is not available to replicate the data sampling from the model. Nevertheless, it may be expected that such errors are relatively minor and appear as random noise in the statistical analysis.

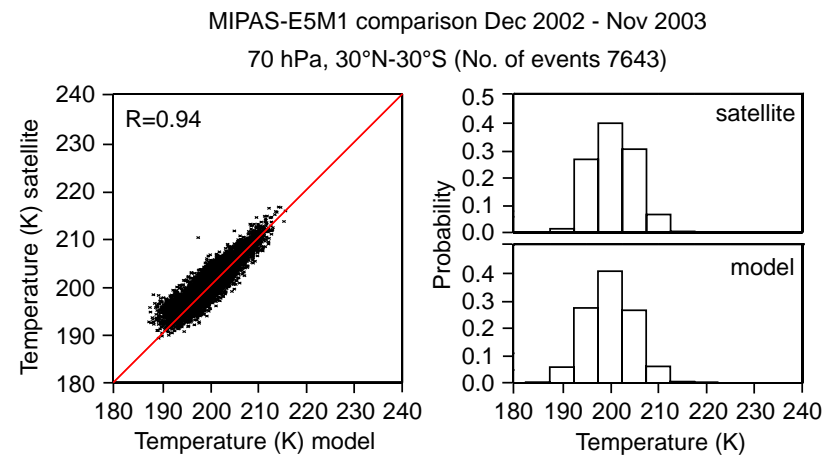

Fig. 4. Comparison of E5M1 temperature calculations with MIPAS at $70 \mathrm{hPa}$ for the period December 2002 to November 2003. The left panel shows a correlation plot, the red line representing ideal agreement, and $\mathrm{R}$ is the correlation coefficient. The right panels show the probability density distributions of the E5M1 model results and the MIPAS data.

In Fig. 3 we show model calculated water vapor mixing ratios at $\sim 100 \mathrm{hPa}$ for four seasons during the period December 2002 to November 2003. These images are qualitatively consistent with previous analyses, e.g. of HALOE data by Randel et al. (2001), although these authors studied an earlier time period. The lowest water vapor mixing ratios 

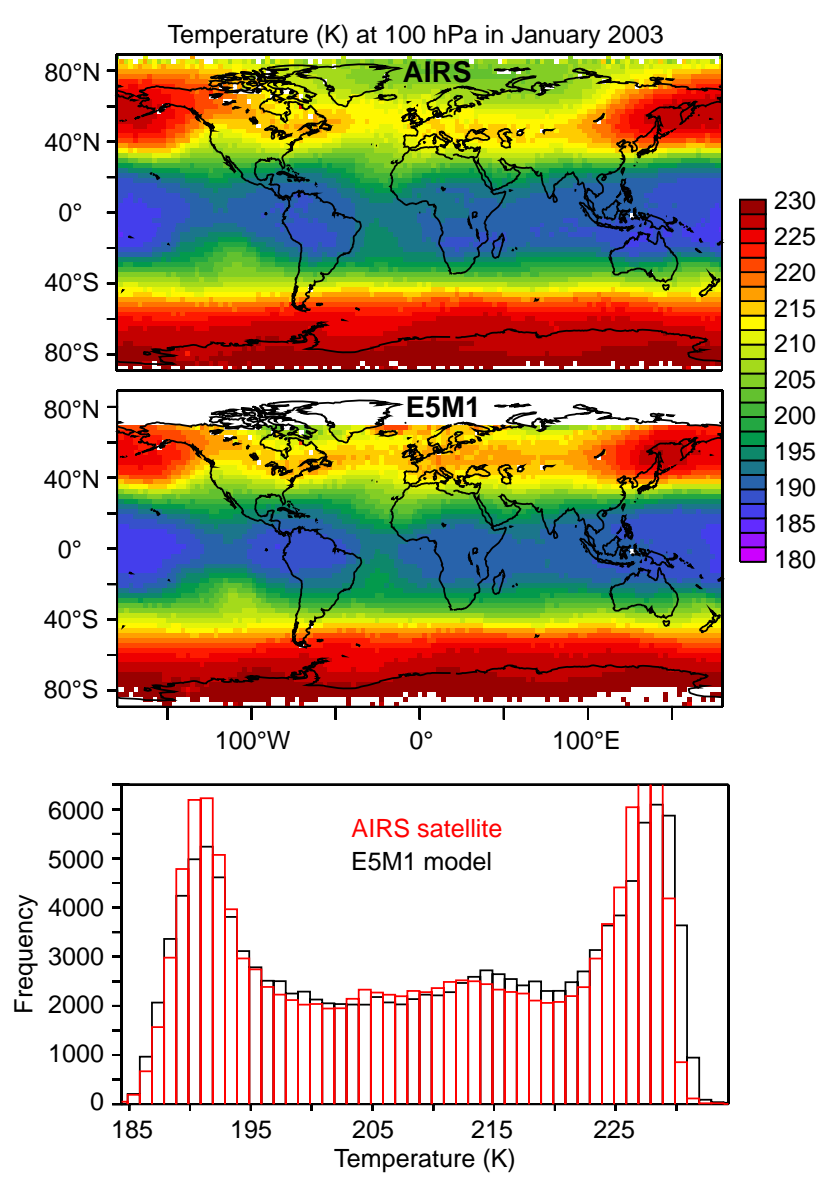

Fig. 5a. Comparison of E5M1 temperature calculations with AIRS satellite measurements at $100 \mathrm{hPa}$ for January 2003. The upper panel shows the "ascending node" AIRS data, taken during daylight conditions outside the Arctic region, and the middle panel the corresponding daytime E5M1 results.

are found over the equatorial western Pacific Ocean during boreal winter (DJF). Highest water vapor mixing ratios, on the other hand, are found further north during boreal summer (JJA) over southern Asia, Central America and in particular over the western Pacific Ocean near $20^{\circ} \mathrm{N}$.

In the lower tropical stratosphere the low temperatures are a consequence of adiabatic cooling in the wave driven largescale ascent, modulated by radiative heating or cooling, being sensitive to spatial distributions of clouds, water vapor and ozone. Figure 4 shows that the model calculated temperatures at $70 \mathrm{hPa}$ agree excellently with the MIPAS measurements during the same period in 2002-2003. The left panel in Fig. 4 shows a correlation plot (correlation coefficient $\mathrm{R}=0.94$ ). In the right panels we present the probability density functions (PDFs) of the model results and MIPAS data.

A comparison of the global model results with AIRS temperature data at $100 \mathrm{hPa}$ is shown in Fig. 5, which corroborates the good agreement. The double-peaked frequency distribution in Fig. 5a for January 2003 manifests the contrasting temperatures between high and low latitudes and the transition zones at $200-220 \mathrm{~K}$. Figure $5 \mathrm{~b}$ presents the temperature distributions in July 2003, with a single peak around $195 \mathrm{~K}$, reflecting the low temperatures in the tropics and partly also at high latitudes in the SH. A second peak, as seen in Fig. 5a, is missing because the relatively highest temperatures are largely restricted to high latitudes in the $\mathrm{NH}$. The linear regression between the satellite observations and the model results, based on about $10^{5}$ collocated data points per month, is 0.99 , and the correlation coefficients are $\mathrm{R}=0.98$ and 0.97 for January and July 2003, respectively.

We emphasize that MIPAS temperature data have a small mean bias of less than $0.5 \mathrm{~K}$, and both MIPAS and AIRS temperature measurements have a total accuracy within $\pm 1.5 \mathrm{~K}$. For individual measurements, as compared in Figs. 4 and 5 , the accuracy may be less, although especially the near-spectral AIRS measurements should be rather accurate. Based on the high correlations between model results and measurements, the realistically simulated spatial distributions and PDFs we conclude that the model accurately reproduces temperatures in the tropical tropopause region and lower stratosphere. This is unlikely to be coincidental, and we interpret it as confirmation that the model realistically simulates the key dynamic and radiation processes.

The water vapor minima and maxima in Fig. 3 coincide with regions of lowest and highest temperatures, respectively (Seidel et al., 2001). It is known that water vapor and temperature correlate near the tropical tropopause, in line with the cold trap concept (Randel et al., 2004; Fueglistaler and Haynes, 2005). In Fig. 6 we investigate this correlation for the inner tropics $\left(10^{\circ} \mathrm{S}-10^{\circ} \mathrm{N}\right)$ in our model results, based on zonal mean temperature and water vapor. The correlation coefficient is generally high year around for the pressure levels 200-90 hPa, $\mathrm{R} \geq 0.8$, and it is highest in boreal winter when dehydration in the equatorial zone is particularly effective.

From April to September the correlation coefficient is lower, especially at 80 and $75 \mathrm{hPa}$, and it breaks down to $\mathrm{R} \leq 0.4$ at $75 \mathrm{hPa}$ during June-August. This is the time of year during which the TTL is strongly influenced by water vapor intrusions from the Asian monsoon (discussed in Sects. (6.46.5). Particularly in the upper TTL the correlation between water vapor and temperature at $10^{\circ} \mathrm{S}-10^{\circ} \mathrm{N}$ during boreal summer diminishes because the transport processes that control water vapor are to a large degree located in the outer tropics. Future work could further exploit the simultaneous water vapor and temperature measurements from satellites (e.g. MIPAS, AIRS) to study the spatial distribution of these parameters and regional differences within the tropics.

In Figs. 7 and 8 we compare the model results with HALOE water vapor data for the period 1997-2005 at the pressure levels 100 and $75 \mathrm{hPa}$, respectively. Both figures indicate that especially the lowest water vapor mixing ratios are simulated accurately, indicating that our model reproduces the dehydration mechanism. Both the model and 

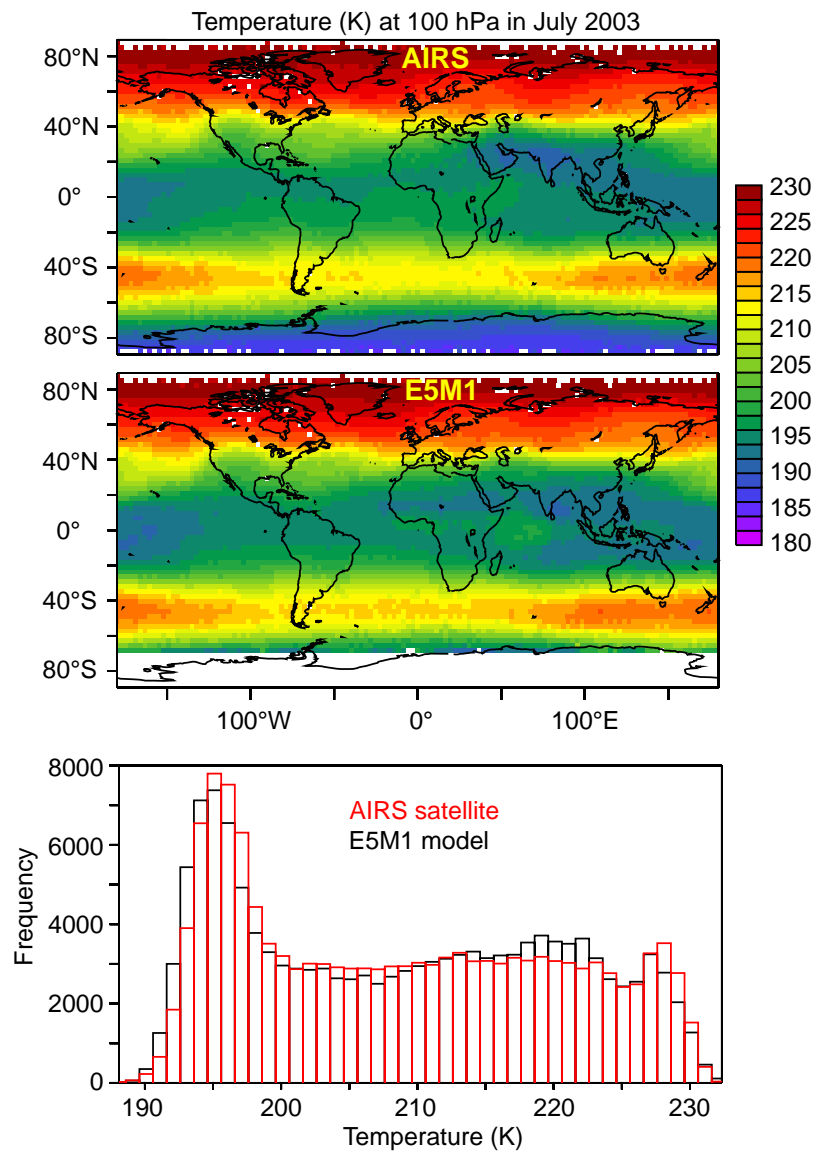

Fig. 5b. Comparison of E5M1 temperature calculations with AIRS satellite measurements at $100 \mathrm{hPa}$ for July 2003. The upper panel shows the "ascending node" AIRS data, taken during daylight conditions outside the Antarctic region, and the middle panel the corresponding daytime E5M1 results.

satellite data show that occasionally very low mixing ratios can occur at $\sim 100 \mathrm{hPa}$, down to nearly $1 \mathrm{ppmv}$. The correlation coefficients between both data sets for the three latitude bands shown are quite high, $0.63 \leq \mathrm{R} \leq 0.75$.

Again, the right panels show the PDFs, providing support for the good agreement at the low end of the water vapor distributions. Note that the tracer PDFs are sensitive to dynamics and mixing processes, and that non-Gaussian (e.g. long-tailed) distributions characterize irregular transport events (Sparling, 2000). The relatively large widths of the distributions indicate substantial variability, which seems to be underestimated in the model results. Especially toward the high end, above $3.5 \mathrm{ppmv}$, the modeled variability is underestimated compared to HALOE. Although the satellite data uncertainty is about $\pm 30 \%$ for the lower stratosphere, the systematic nature of the model-measurement difference suggests that our model results may be biased, as discussed in more detail in Sect. 6.4.

The lower left panel of Fig. 7 indicates that in a few cases

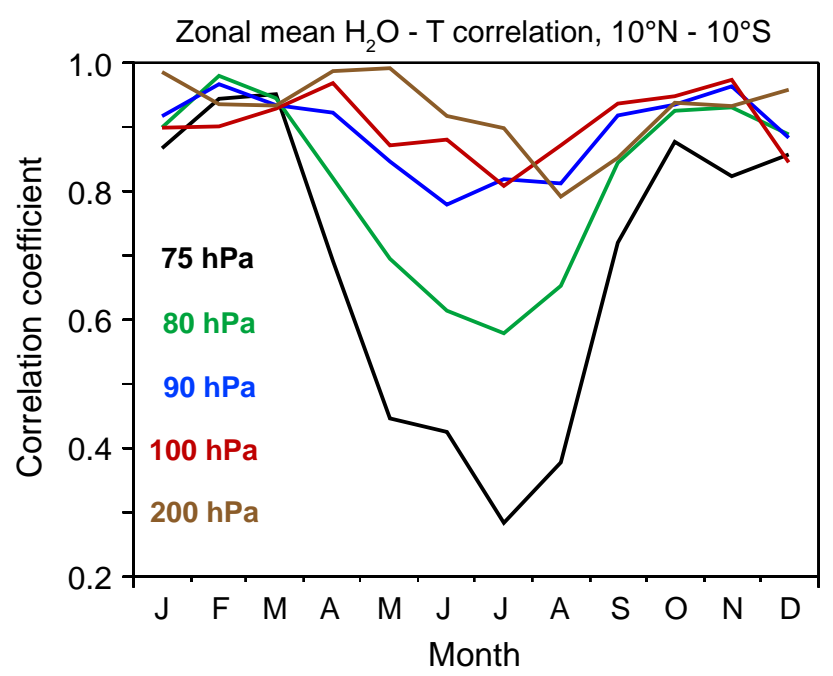

Fig. 6. Model calculated correlation coefficients (R) between zonal mean water vapor and temperature in the latitude band $10^{\circ} \mathrm{S}$ to $10^{\circ} \mathrm{N}$ at different altitudes for the period 1996-2005.

relatively high mixing ratios are calculated in locations that are dryer in the observations, which could be related to sampling errors or time shifts between computed and real events of high humidity at $\sim 100 \mathrm{hPa}$. Both in the model results and satellite data, the PDFs are wider at $10^{\circ} \mathrm{N}-30^{\circ} \mathrm{N}$ than at $10^{\circ} \mathrm{S}-30^{\circ} \mathrm{S}$. The PDF for the inner tropics at $10^{\circ} \mathrm{S}-10^{\circ} \mathrm{N}$, shown in the upper panel, is intermediate between both hemispheres. In Sect. 6.4 we compare modeled time series with HALOE data, and show that deviations between calculations and measurements are largest in the $\mathrm{NH}$, associated with the Asian monsoon, and that the bias is time dependent, associated with a drying tendency.

The model-measurement correlation plots and PDFs for $70 \mathrm{hPa}$ in Fig. 8 are compacter and narrower than for $100 \mathrm{hPa}$, respectively. The agreement is again rather good, and the correlation coefficients are similar to those for $100 \mathrm{hPa}$, $0.60 \leq \mathrm{R} \leq 0.77$. The very low water vapor mixing ratios seen at $100 \mathrm{hPa}$ are rare at $70 \mathrm{hPa}$, and data points below $2 \mathrm{ppmv}$ are absent. The variability is generally less at $70 \mathrm{hPa}$ as a result of zonal and meridional mixing in the upper TTL. Both the correlation plots and the PDFs show best agreement toward low mixing ratios, and also reveal a lack of modeled variability in the upper part of the range. In the inner tropics at $10^{\circ} \mathrm{S}-10^{\circ} \mathrm{N}$, shown in the upper panel of Fig. 8, the satellite measurements suggest a bimodal PDF, a consequence of moist events originating in higher latitudes. The model PDF only shows a weak bimodality as the peak at $\sim 3.5 \mathrm{ppmv}$ is underrepresented.

\subsection{Dehydration mechanism}

Our model results show that water vapor mixing ratios at the tropical tropopause are not zonally uniform (Fig. 3), although 
HALOE-E5M1 comparison 1997-2005

$100 \mathrm{hPa}, 10^{\circ} \mathrm{S}-10^{\circ} \mathrm{N}$ (No. of events 1980 )
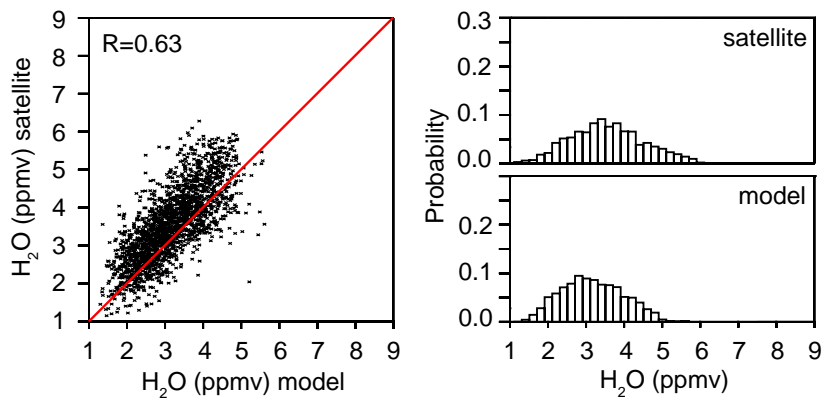

$100 \mathrm{hPa}, 30^{\circ} \mathrm{S}-10^{\circ} \mathrm{S}$ (No. of events 4759 )
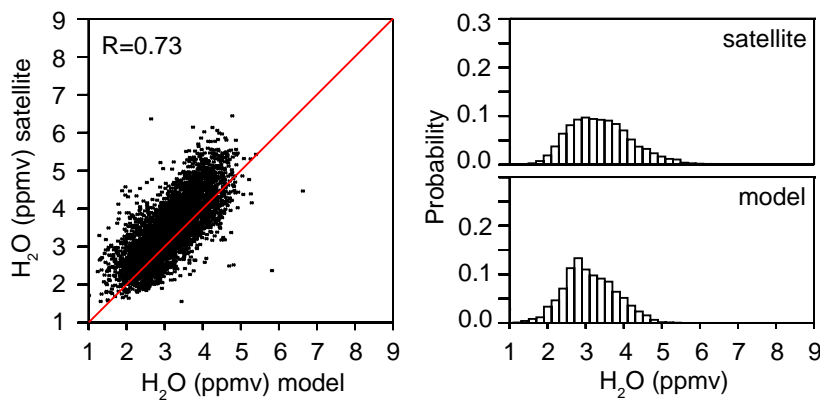

$100 \mathrm{hPa}, 10^{\circ} \mathrm{N}-30^{\circ} \mathrm{N}$ (No. of events 4152 )
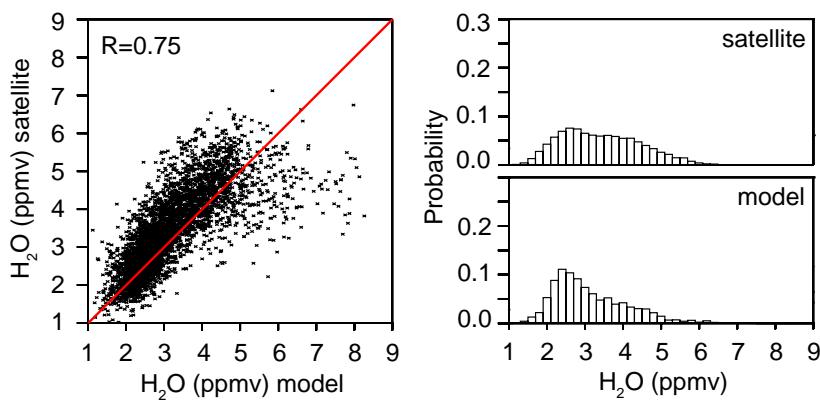

Fig. 7. Comparison of E5M1 water vapor calculations with HALOE at $100 \mathrm{hPa}$ for the period 1997-2005.

the differences vanish upward through transport and mixing. Holton and Gettelman (2001) emphasized the relatively short time scale of horizontal relative to vertical transport in the TTL and stratosphere. The lower stratosphere is generally driest in the Indo-Pacific region during NH winter. The modeled temporal and vertical distribution of "dryness" in Fig. 9a clearly shows the lowest mixing ratios during the DecemberMarch period.

Figure 9 includes the accompanying temperature distribution, illustrating that the driest regions $(<2.5 \mathrm{ppmv})$ are also the coldest ( $<192 \mathrm{~K}$ ). Furthermore, Fig. 9a demonstrates that occasionally the water vapor minimum is more distinct at $75 \mathrm{hPa}$, well above the tropopause, consistent with the observed hygropause. Although the hygropause is caused by the upward migration of the water vapor minimum in the tape recorder, it can be deepened by continuing dehydration above
HALOE-E5M1 comparison 1997-2005

$70 \mathrm{hPa}, 10^{\circ} \mathrm{S}-10^{\circ} \mathrm{N}$ (No. of events 3710 )
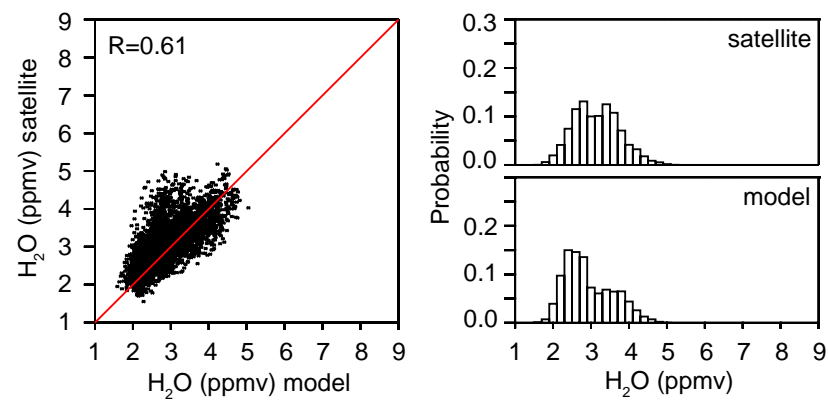

$70 \mathrm{hPa}, 30^{\circ} \mathrm{S}-10^{\circ} \mathrm{S}$ (No. of events 5423 )
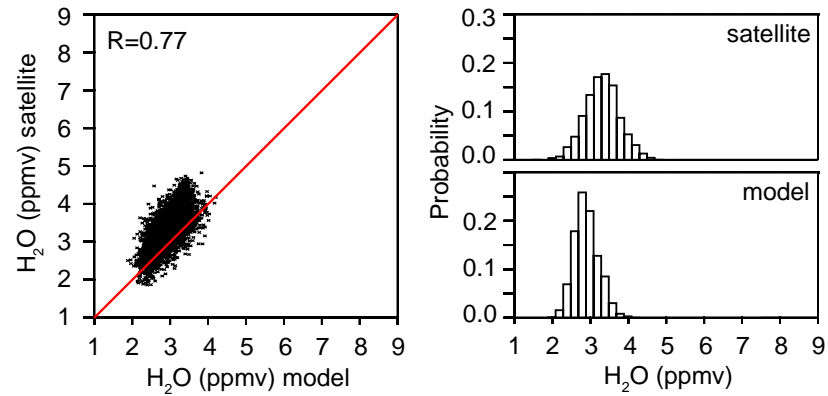

$70 \mathrm{hPa}, 10^{\circ} \mathrm{N}-30^{\circ} \mathrm{N}$ (No. of events 4977 )
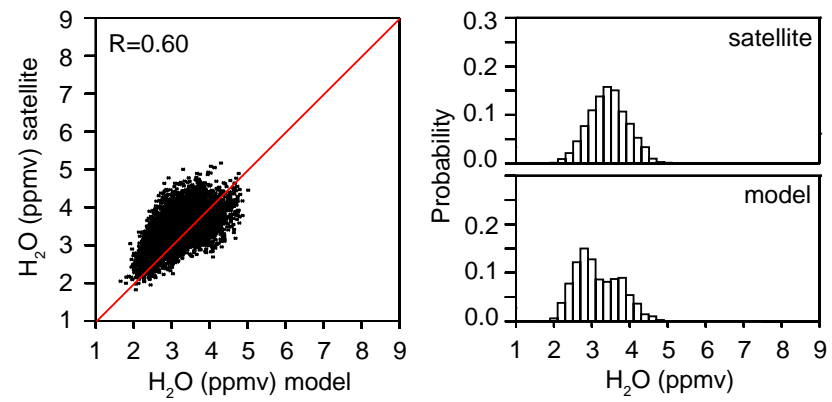

Fig. 8. Comparison of E5M1 water vapor calculations with HALOE at $70 \mathrm{hPa}$ for the period 1997-2005.

the tropopause. Figure 9a also reveals that during NH winter the water minima ascend from 100 to $75 \mathrm{hPa}$ in about a month, i.e. at a mean speed of a few $\mathrm{m} /$ hour.

The tropical upwelling is brought about by the large-scale wave forcing, which has a maximum during DecemberMarch. Through adiabatic expansion and consequent cooling it contributes to the low tropopause temperatures (Yulaeva et al., 1994). The adiabatic cooling tends to be balanced by radiative heating (Holton et al., 1995), while on a regional scale heating may actually contribute significantly to the upwelling (Plumb and Eluszkiewicz, 1999). In the region beneath the deep tropical convection produces anvil clouds, and above these clouds the heating is blocked and the upwelling decelerates. The deep convective clouds initially moisten the upper troposphere through the transport of saturated air, and the air is subsequently desiccated as it slowly travels through 


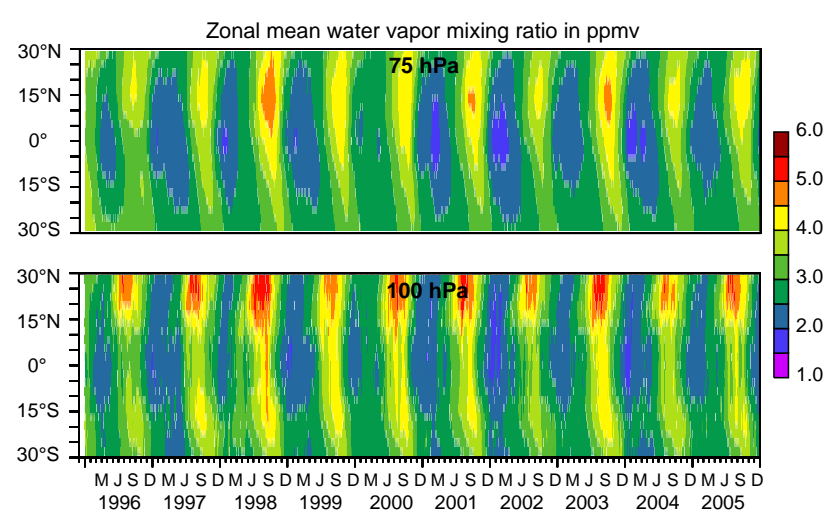

Fig. 9a. Time series of model calculated zonal mean water vapor (ppmv) between $30^{\circ} \mathrm{N}$ and $30^{\circ} \mathrm{S}$ latitude, at the pressure altitude levels of about 100 and $75 \mathrm{hPa}$.

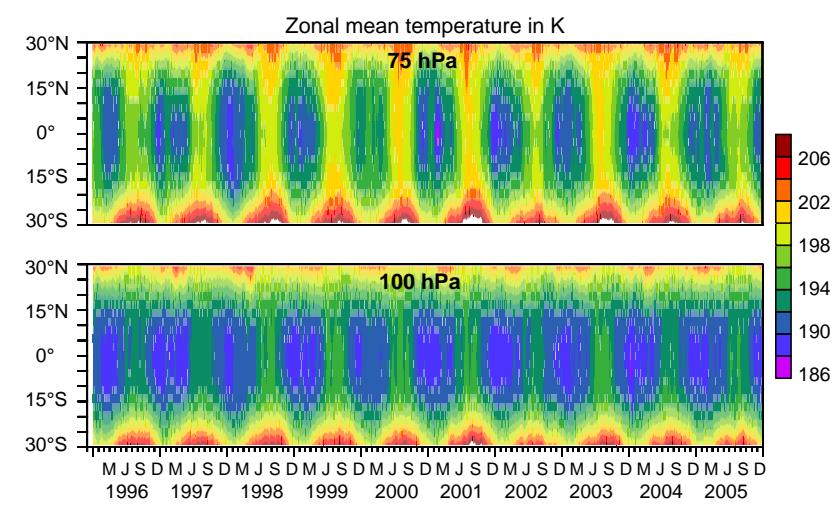

Fig. 9b. Time series of model calculated zonal mean temperature (K) between $30^{\circ} \mathrm{N}$ and $30^{\circ} \mathrm{S}$ latitude, at the pressure altitude levels of about 100 and $75 \mathrm{hPa}$.

the TTL, also shown by observational and Lagrangian modeling studies (Vömel et al., 2002; Jensen and Pfister, 2004).

Hence, the ascent through the TTL is accompanied by net cooling, which maintains a high relative humidity and sustains water condensation on upward advected particles. Our model results indicate that on average net radiative cooling up to several $\mathrm{K} /$ day is prevalent at $\sim 200 \mathrm{hPa}$ throughout the year, while it decreases with altitude within the TTL. If the radiative cooling would be stronger it could balance the wave driven ascent and even contribute to subsidence (Fueglistaler and $\mathrm{Fu}, 2006)$. Figure 10 presents model calculated net radiative heating rates at the tropopause and in the lower stratosphere for winter and summer 2003. These indicate that near the tropical tropopause at $\sim 100 \mathrm{hPa}$ radiative heating prevails and therefore the cooling conditions are largely restricted to the layer beneath.

With increasing altitude in the TTL the $\mathrm{O}_{3}$ concentration and the consequent radiative heating increase. However, thick convective clouds below can block the IR heating from

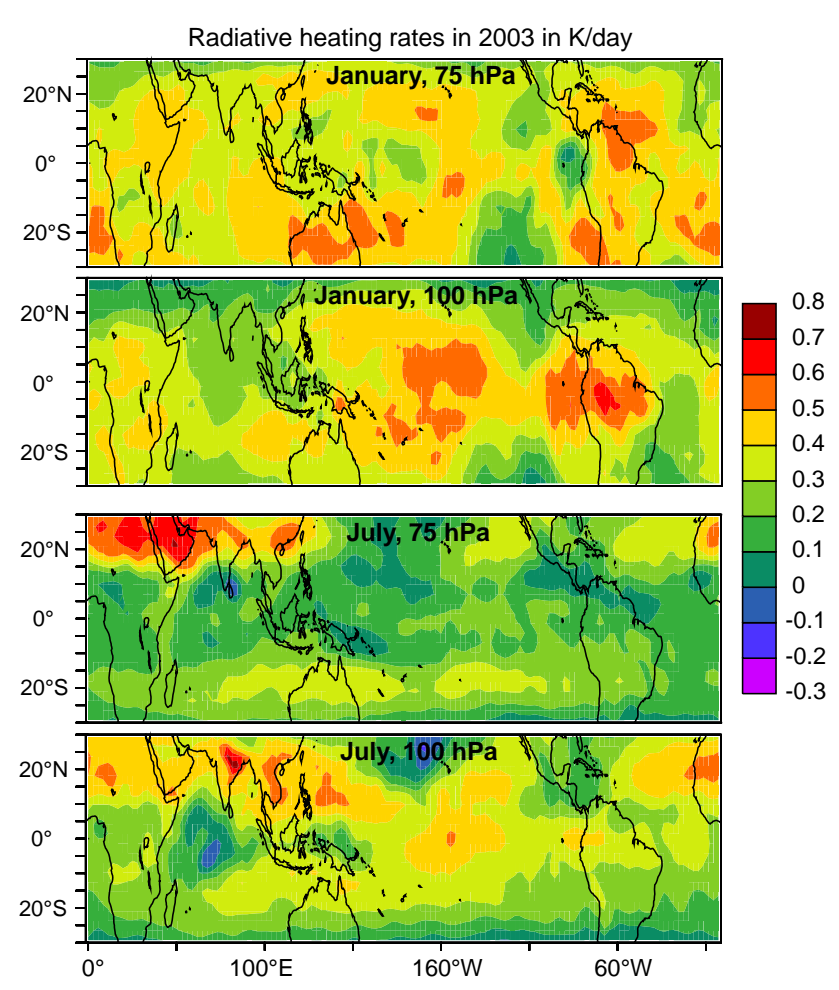

Fig. 10. Model calculated net radiative heating rates at about 75 and $100 \mathrm{hPa}$ in January and July 2003.

the lower troposphere so that freezing conditions are maintained. As a result of continual saturation over ice within the coldest regions of the TTL, thin cirrus clouds are formed above the convective anvils. The presence of tropopause cirrus clouds has been confirmed by aircraft measurements (McFarquhar et al., 2000; Thomas et al., 2002; Peter et al., 2003), although it cannot be determined with confidence to what degree they are remnants of anvils or are formed within the TTL. In our model both are possible because water is transported in all phases. However, the modeled upward water transport is dominated by vapor, indicating that thin cirrus cloud presence is governed by in situ formation.

Figure 11 presents the model calculated mean ice water mixing ratios within the TTL. It shows TTL cirrus clouds, representing a mean water mixing ratio of a few ppmv at $150 \mathrm{hPa}$ and about $0.1 \mathrm{ppmv}$ at $100 \mathrm{hPa}$, which are largely collocated with deep convection, in agreement with satellite measurements (Wylie and Wang, 1997; Massie et al., 2002; Dessler et al., 2006). As long as the cirrus clouds overlie their cold cumulonimbus parents they contribute to radiative cooling. However, after the cumulonimbus anvils decay, the thin ice clouds become subjected to IR from the lower and warmer troposphere; hence, radiative heating intensifies and accelerates the transport into the stratosphere. Such radiatively driven ascent of thin ice clouds is known as "cirrus lofting" (Corti et al., 2006). 


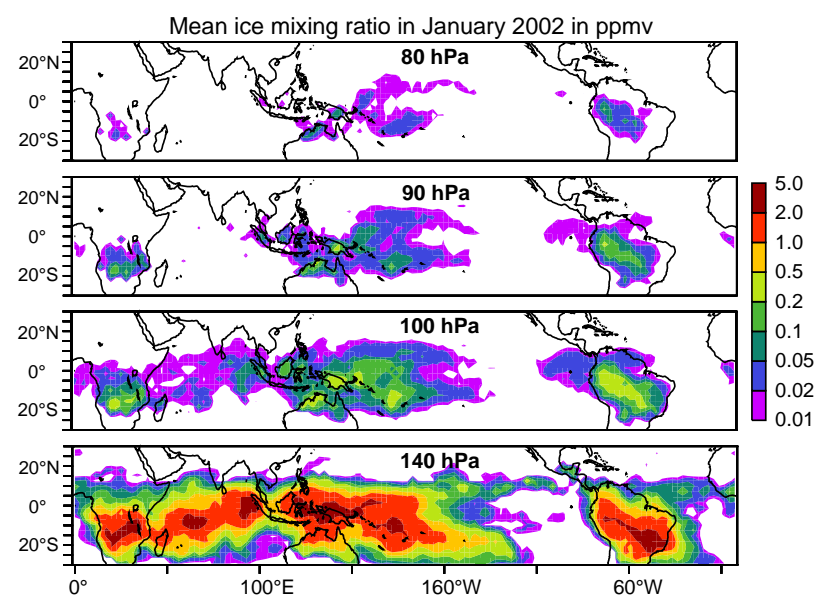

Fig. 11a. Model calculated mean ice water mixing ratios (ppmv) at about 140, 100, 90 and $80 \mathrm{hPa}$ in January 2002.

Thus, the TTL drying results from the sedimentation of ice crystals that have formed within the TTL, mostly between 200 and $100 \mathrm{hPa}$ altitude. Our model does not account for cirrus microphysical details and neglects the occurrence of supersaturation. This suggests that cloud formation, notably the amount of condensate, may not be very sensitive to these details, also indicated by sensitivity studies of Bonazzola and Haynes (2004). Nevertheless, observations show supersaturation is ubiquitous (Gettelman et al., 2006b), which indicates that the availability of ice nuclei may be a limiting factor, i.e. delaying cloud formation. It is therefore conceivable that the number of ice nuclei affects the crystal size distribution and consequently particle sedimentation rates and radiative properties, which should be studied in greater detail with advanced parameterization schemes.

In our model the drying is strongest between $200 \mathrm{hPa}$ and the tropical tropopause, although some ice clouds extend to higher altitudes so that dehydration can continue aloft. A detailed comparison of Figs. 9 and 11 shows that the water minima can occur north of the cloud maxima, which is also observed from satellites (Randel et al., 2001), being the result of the northerly flow component in the regions of dehydration. The ice clouds are actually sustained by horizontal transport of water vapor (Holton and Gettelman, 2001). Our model computes TTL cirrus clouds throughout the year; however, their location varies with that of deep convection and the cold regions aloft.

\subsection{Moistening and drying periods}

Figure 9 shows that during NH summer, both water vapor mixing ratios and temperatures in the tropical lower stratosphere are substantially higher than in winter. Nevertheless, also in this season the coldest tropopause temperatures coincide with the driest conditions. The winter and summer drying mechanisms are the same, i.e. cirrus cloud formation

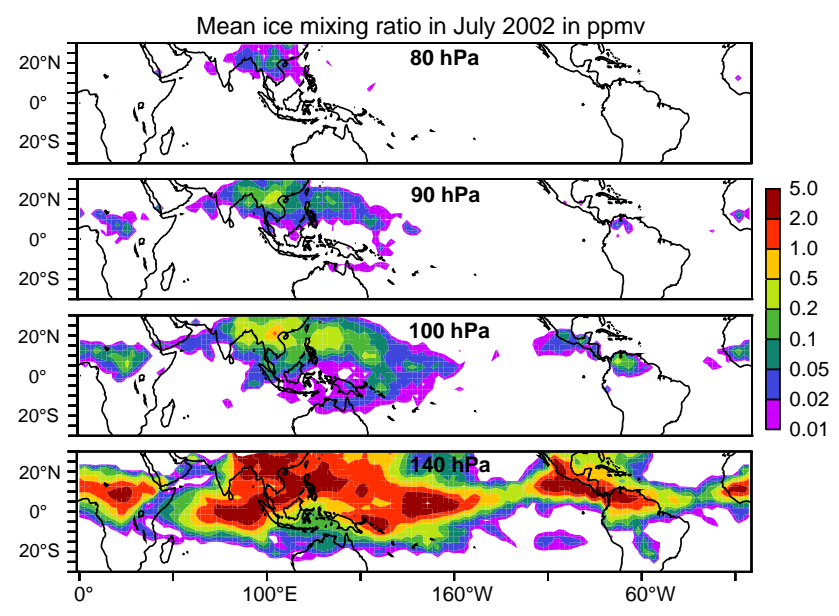

Fig. 11b. Model calculated mean ice water mixing ratios (ppmv) at about 140, 100, 90 and $80 \mathrm{hPa}$ in July 2002.

and ice particle sedimentation above convective anvils, but the geographical locations and effectiveness differ.

The extra-tropical wave forcing in NH summer is about half that in winter, so that tropical upwelling and adiabatic cooling are reduced. The $\mathrm{H}_{2} \mathrm{O}$ contours at $100 \mathrm{hPa}$ in Fig. 9a appear at $75 \mathrm{hPa}$ in about 2-3 months, i.e. traveling upward very slowly by about $1 \mathrm{~m} /$ hour. Our model generates the TTL cirrus further north than in winter (Fig. 11). Part of the TTL cirrus occurs over Southeast Asia, coincident with the very deep monsoon convection. Our model generates the deepest convection in this region, e.g. deeper than in the equatorial region during NH winter. Figure $11 \mathrm{~b}$ shows that over Southeast Asia the TTL cirrus can extend to relatively high altitudes. Consequently, the ice particles are more likely to evaporate within the TTL rather than sediment large distances and contribute to dehydration.

Figure 9a shows that near the tropical tropopause $(\sim 100 \mathrm{hPa})$ the meridional $\mathrm{H}_{2} \mathrm{O}$ distribution is relatively disperse, i.e. affected by synoptic events, while the contours become more distinct with increasing altitude $(75 \mathrm{hPa})$. This feature is related to meridional transport and mixing in the lower stratosphere (Rosenlof, 1995; Volk et al., 1996). During $\mathrm{NH}$ summer the meridional transports extend relatively far north, controlled by the Tibetan High, a large quasistationary anticyclone in the upper troposphere and lower stratosphere, extending from the Mediterranean to the Pacific between about $10^{\circ}$ and $40^{\circ} \mathrm{N}$ latitude.

It is located over the Asian monsoon surface trough and carries air poleward at its western flank over the Middle East and equatorward at its eastern flank near the Asian Pacific Rim. This air is relatively humid owing to the deep penetration of monsoon convection, and it plays a key role in moistening the stratosphere (Bannister et al., 2004; Gettelman et al., 2004a; Fueglistaler et al., 2005; Fu et al., 2006). In Sect. (6.5) we address the associated transport routes and vertical fluxes of water vapor in more detail. 


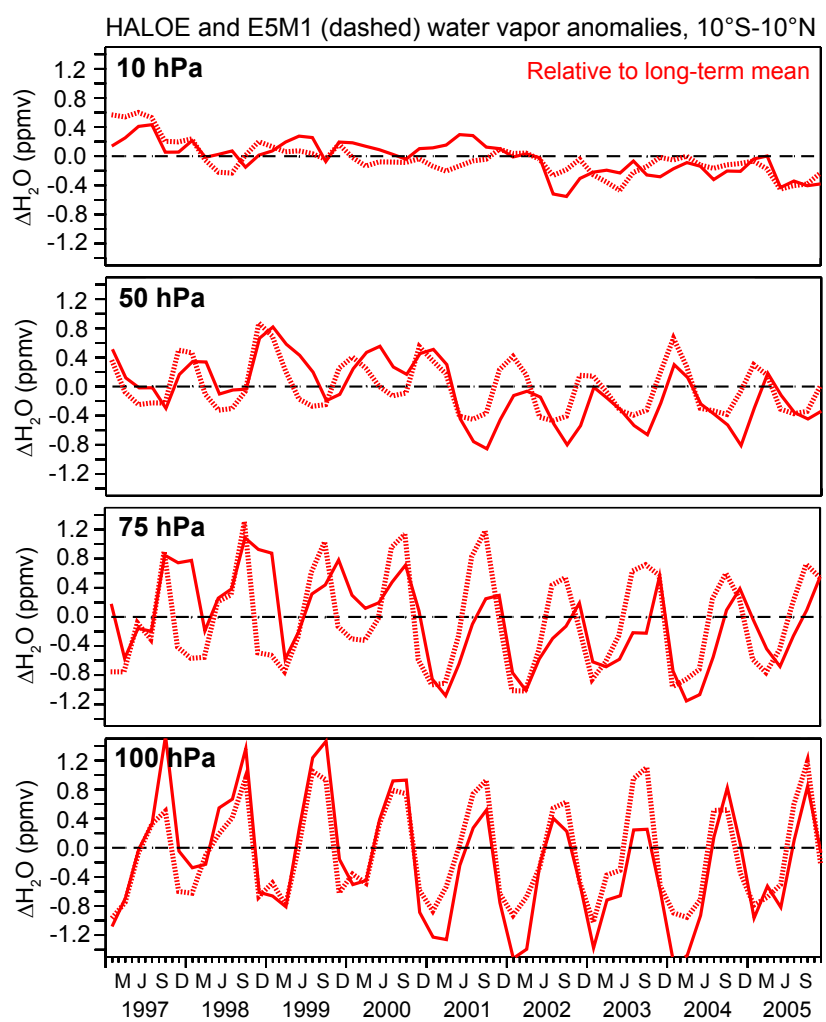

Fig. 12a. Tropical water vapor tendencies derived from HALOE measurements (solid lines) and model calculations (dashed lines). Shown are the 2-monthly mean anomalies relative to the long-term mean.

During El Niño events tropical tropopause temperatures can be increased, e.g. over the western Pacific region, and our model results for the strong El Niño of 1997/98 show relatively high coincident water vapor mixing ratios, most pronounced at the end of the event in the summer of 1998. Nevertheless, in view of the inter-annual water vapor variability near the tropical tropopause (Figs. 1 and 2) and at $75 \mathrm{hPa}$ (Fig. 9a), it is not obvious that this El Niño year was exceptional, especially during boreal winter. Both model and satellite data indicate similarly moist periods in the equatorial lower stratosphere during non-El Niño years, although our model seems to underestimate humidity at $100 \mathrm{hPa}$ during the autumn and winter of 1997/1998.

Bonazzola and Haynes (2004) argued that during El Niño and La Niña years, both the regions of minimum temperatures and transport pathways are shifted. Therefore, El Niño events alter the regions of dehydration; however, they do not strongly influence the overall moisture transport into the stratosphere. In fact, our model results show that much of the inter-annual variability in water vapor, including in the $10^{\circ} \mathrm{N}-10^{\circ} \mathrm{S}$ latitude band, coincides with water vapor anomalies in the outer tropics, especially in the NH, suggestive of a link with the Asian monsoon.

In Fig. 12 we present long-term (red) and deseasonalized (black) tropical water vapor anomalies, derived both from
HALOE and E5M1 (dashed) water vapor anomalies, $10^{\circ} \mathrm{S}-10^{\circ} \mathrm{N}$
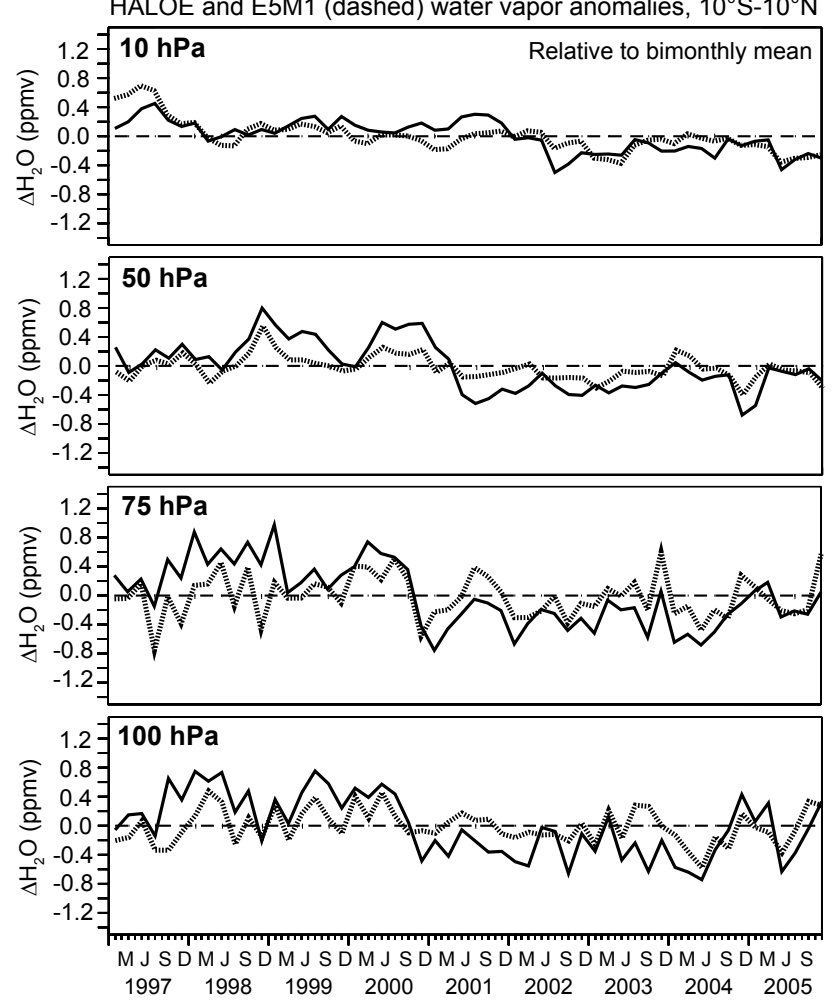

Fig. 12b. Tropical water vapor tendencies derived from HALOE measurements (solid lines) and model calculations (dashed lines). Shown are the 2-monthly deseasonalized anomalies.

HALOE measurements and model calculations. Note this involves near point-to-point comparisons of these datasets as the model results were sampled at the locations closest to those of the HALOE measurements. We skip the first year (1996) because the model is too close to the initial conditions, as prescribed from HALOE data. We average over 2-monthly periods because the HALOE dataset is sparse, especially at $100 \mathrm{hPa}$ and since 2001 . Figure 12 shows that the timing and amplitude of the seasonal and inter-annual variability in the model is remarkably similar to the HALOE observations, and Fig. 12a illustrates that the seasonal amplitude falls off with altitude, hence the tape recorder signal vanishes.

From the HALOE water vapor measurements in the lower tropical stratosphere it appears that pre-2001 years were moister than the subsequent period (Fig. 2). Randel et al. (2006) analyzed HALOE data between $60^{\circ} \mathrm{S}$ and $60^{\circ} \mathrm{N}$, and concluded that stratospheric water vapor shows a substantial and persistent decrease since 2001, linked to changes in the tropical tropopause and the large-scale circulation. Some caution with strong conclusions is called for, because the number of HALOE observations dropped by about a factor of two since 2001, and the sampling changed nonsymmetrically between both hemispheres and between sunrise and sunset occultation. 
Notwithstanding these reservations, our analysis of tropical water vapor from $\mathrm{HALOE}$ measurements $\left(10^{\circ} \mathrm{S}-10^{\circ} \mathrm{N}\right)$ in Fig. 12b confirms the occurrence of a negative anomaly at $100 \mathrm{hPa}$ after the year 2000, being compelling because it seems to propagate upward in the tape recorder. This event is smaller in our model results and therefore we cannot provide a convincing explanation. Based on our model results we would rather classify it as variability. It should be stressed that the comparison presented here involves the exact pressure levels from the model, whereas the HALOE data represent layers of a few kilometers thickness. If the satellite data would be available together with the averaging kernel of the retrieval algorithm, we could further improve the comparison and infer possible artifacts from vertical integration.

Interestingly, the drying event in 2001 may also be conceived as an episode that coincides with the solar cycle maximum in 2000-2002, an issue that deserves further investigation. It may also be worth looking into a link with the Antarctic vortex split in SH spring 2002 since the water vapor anomaly arrived at about $10 \mathrm{hPa}$ in September of that year, possibly associated with perturbed wave propagation. Alternatively, the episode may be interpreted as part of interdecadal water vapor variability, given the very similar mixing ratios at the beginning and the end of the studied period, especially at 100 and $75 \mathrm{hPa}$ (Fig. 12).

A longer term negative tendency seems most apparent in the middle stratosphere at $10 \mathrm{hPa}$, both in the HALOE data and the model results (Fig. 12). In fact, by using all data from our model, i.e. not only the HALOE collocated subset in Fig. 12, we find a significant negative tendency of about $0.5 \mathrm{ppmv} /$ decade in most of the stratosphere except in the extra-tropical lower stratosphere in the SH. Again, this points to the Asian monsoon, which will need to be investigated in greater detail.

In the upper stratosphere and mesosphere we must furthermore account for a drying tendency since about 1997, associated with the solar cycle. In our model enhanced depletion of water vapor by Lyman- $\alpha$ photodissociation continues until solar maximum in 2000-2002 (Fig. 1b). After 2002 this tendency reversed, to continue until solar minimum in 2007, which counteracts the overall negative tendency, although this is unlikely to have a strong influence on the tropical stratosphere. Further analyses of stratospheric water vapor trends should consider these multiple influences and the substantial inter-annual and inter-decadal variability, and include longer term measurements and model calculations than the period considered here.

\subsection{Troposphere-to-stratosphere fluxes}

To determine vertical mass exchanges in the tropopause region we diagnostically applied the ATTILA Lagrangian transport scheme for the years 2002 and 2003. As indicated earlier, upward transport into the stratosphere is not restricted to the tropics, and the "turnaround" zones where the mean vertical fluxes are just about zero are located at $30^{\circ}-35^{\circ}$ (Rosenlof, 1995). We calculate that between $30^{\circ} \mathrm{N}$ and $30^{\circ} \mathrm{S}$ the mean upward air mass flux across $200 \mathrm{hPa}$ is $35.2 \times 10^{9}$ $\mathrm{kg} / \mathrm{s}$, and the same amount of air descends poleward of $35^{\circ}$ latitude. Approximately one quarter of the upward flux at $200 \mathrm{hPa}$ subsequently enters the stratosphere at $100 \mathrm{hPa}$, in good agreement with an earlier estimate (Rosenlof and Holton, 1993), and $\sim 15 \%\left(5.8 \times 10^{9} \mathrm{~kg} / \mathrm{s}\right)$ traverses $75 \mathrm{hPa}$.

Hence the TTL is to a large extent ventilated back into the troposphere, consistent with tracer measurements by aircraft suggesting a recirculation between the lower stratosphere and upper troposphere (Tuck et al., 1997). The accompanying annual upward water flux across $200 \mathrm{hPa}$ is $7.8 \times 10^{6}$ $\mathrm{kg} / \mathrm{s}$, while merely about $0.1 \%$ of this water mass, $11.2 \times 10^{3}$ $\mathrm{kg} / \mathrm{s}$, reaches $75 \mathrm{hPa}$. This illustrates the high efficiency by which the air is desiccated, reducing the annual zonal mean water mixing ratio from roughly $100 \mathrm{ppmv}$ at $200 \mathrm{hPa}$ to $3-$ $3.5 \mathrm{ppmv}$ at $75 \mathrm{hPa}$, whereby the desiccation largely occurs in the 100-200 $\mathrm{hPa}$ region.

Although $\mathrm{CH}_{4}$ oxidation strongly affects water vapor in the upper stratosphere, it contributes relatively little to the overall stratospheric water loading. On average, approximately $1.25 \times 10^{3} \mathrm{~kg} / \mathrm{s} \mathrm{CH}_{4}$ is oxidized within the stratosphere, which produces less than $3 \times 10^{3} \mathrm{~kg} / \mathrm{s} \mathrm{H}_{2} \mathrm{O}$. Since the annual mean upward $\mathrm{H}_{2} \mathrm{O}$ flux across the $100 \mathrm{hPa}$ level is about $23 \times 10^{3} \mathrm{~kg} / \mathrm{s}$, it follows that transport from the tropopause contributes more than $85 \%$. By considering the $\mathrm{H}_{2} \mathrm{O}$ flux across $75 \mathrm{hPa}$ this would be about $75 \%$.

Furthermore, the above mentioned model calculated water mixing ratio at the stratospheric entry between $30^{\circ} \mathrm{N}$ and $30^{\circ} \mathrm{S}(3-3.5 \mathrm{ppmv})$ demonstrates that the annual mean tropopause mixing ratio in the inner tropics, i.e. within $10^{\circ}$ latitude from the equator (2-2.5 ppmv), is not representative of the overall moisture transport into the stratosphere, and that additional water is entrained from higher latitudes.

Figure 13 presents the model diagnosed vertical water mass fluxes across the isentropic levels of 340, 380 and $420 \mathrm{~K}$, roughly equivalent to the 200,100 and $75 \mathrm{hPa}$ pressure levels. Here we use potential temperature rather than pressure coordinates to visualize areas of upward and downward motion, assuming that in absence of diabatic processes air parcels move along rather than across isentropic surfaces. Nevertheless, the annual mass fluxes across the isentropic and isobaric levels are similar (within $\sim 10 \%$ ) but seasonally the differences can be larger. Comparing the lower panels of Fig. 3 to Fig. 11 illustrates that the upward moisture transports in regions of strong convection coincide with the presence of TTL cirrus. At $340 \mathrm{~K}$ upward motion is dominated by convection, while the picture entirely changes at $380 \mathrm{~K}$ (middle panels of Fig. 13).

In $\mathrm{NH}$ winter at the tropical tropopause the regions of strong convection and associated water transport over Indonesia and the western Pacific Ocean are characterized by relatively minor vertical motion at 380 and $420 \mathrm{~K}$ (Fig. 13a). Thus the geographic regions of strongest convective mass 


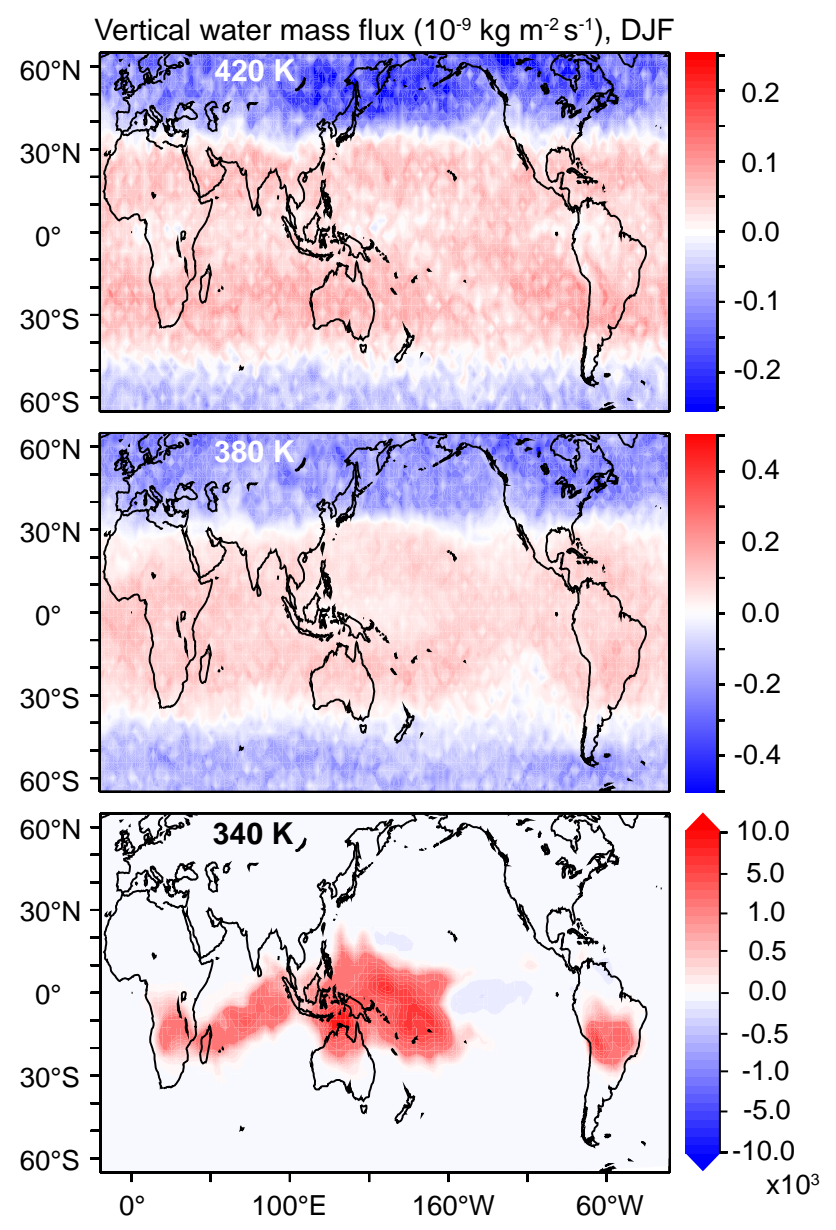

Fig. 13a. Model calculated water mass fluxes across the 340, 380 and $420 \mathrm{~K}$ isentropic surfaces, averaged for the periods DecemberFebruary 2002 and 2003 in units $10^{-9} \mathrm{~kg} \mathrm{~m}^{-2} \mathrm{~s}^{-1}$ (red is upward). Note the scale changes between panels.

fluxes in the troposphere are not the regions where air primarily enters the stratosphere. Based on operational wind data over Indonesia it has been shown that air mass fluxes at the tropopause can even be downward, thus representing a stratospheric "drain" (Sherwood, 2000). Our model occasionally calculates descent over Indonesia at $100 \mathrm{hPa}$ $(380 \mathrm{~K})$, although vertical velocities are very low. This regional inhibition of upward mass transport at the tropical tropopause is caused by radiative cooling above the cold cloud tops, which rivals the extra-tropical wave driven upwelling. A relatively pronounced drain in our model occurs over the tropical Indian Ocean during NH summer (Fig. 13b). This phenomenon coincides with net radiative cooling at the tropopause over the extensive cumulonimbus anvils during a period when the wave-driving is weak, as shown in the lower panel of Fig. 10. As a consequence, the zonal average vertical motion at $100 \mathrm{hPa}$ during $\mathrm{NH}$ summer in the tropics is small or partly even downward, which can lead to shallow recirculation of air around the tropopause. At the

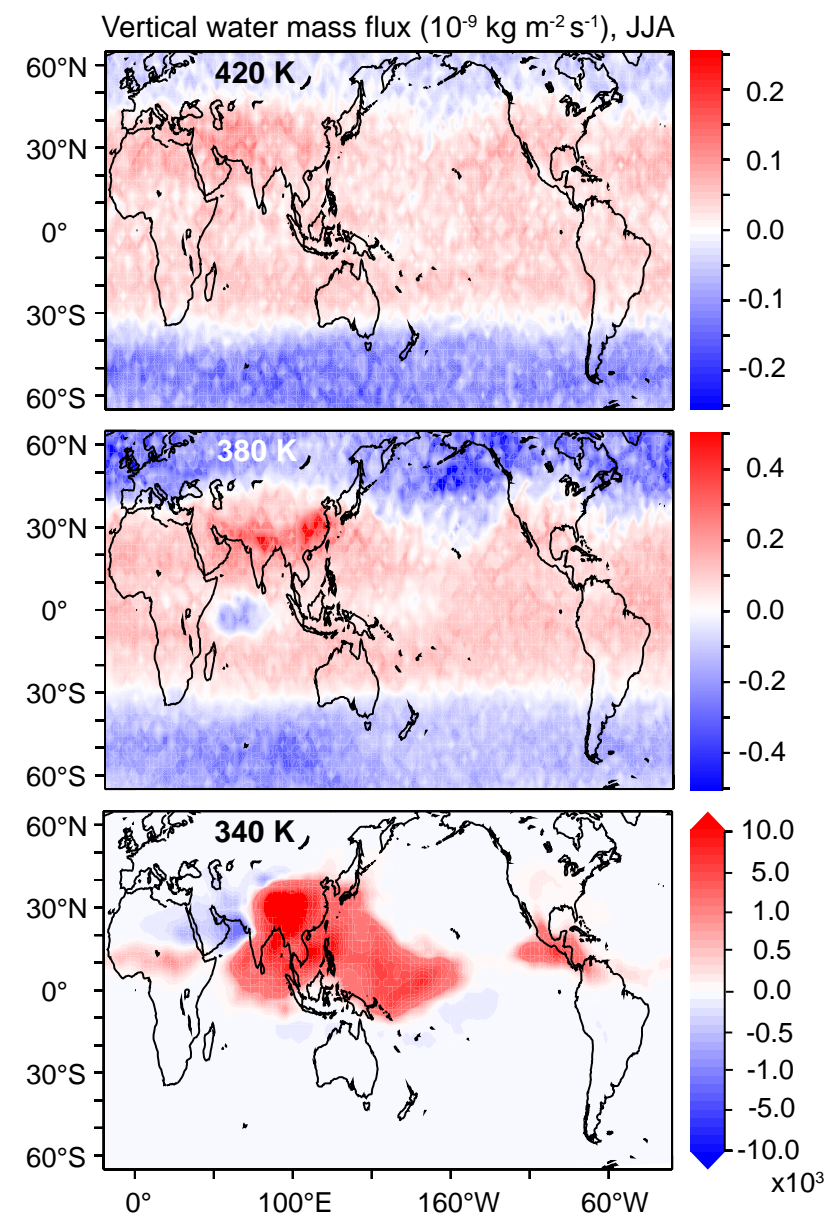

Fig. 13b. Model calculated water mass fluxes across the 340 , 380 and $420 \mathrm{~K}$ isentropic surfaces, averaged for the periods JuneAugust 2002 and 2003 in units $10^{-9} \mathrm{~kg} \mathrm{~m}^{-2} \mathrm{~s}^{-1}$ (red is upward). Note the scale changes between panels.

tropopause and in the lower stratosphere upward transport is stronger adjacent to the regions of strong convection and cumulonimbus anvil presence. Here $\mathrm{H}_{2} \mathrm{O}, \mathrm{O}_{3}$ and remnants of TTL cirrus in the moist convective outflow contribute to net radiative heating, i.e. being subject to IR radiation from the lower troposphere, not blocked by the anvil clouds underneath. Therefore, at altitudes around $100-75 \mathrm{hPa}(380-$ $420 \mathrm{~K}$ ) upward motion and transport of water vapor to a large extent occurs between about $10^{\circ}$ and $30^{\circ}$ latitude (Fig. 13). This vertical transport pattern is most pronounced in Southeast Asia, centered over the Tibetan Plateau (Fig. 13b), where convection is very deep, in agreement with the satellite data analysis by Fu et al. (2006).

Fu et al. (2006) hypothesized that convection by elevated surface heating over the Tibetan Plateau is particularly deep and detrains more water than elsewhere. Our model results support this hypothesis and corroborate that the ice particles formed in the deepest convective outflow are less likely to escape the TTL. The particles would have to grow to relatively 


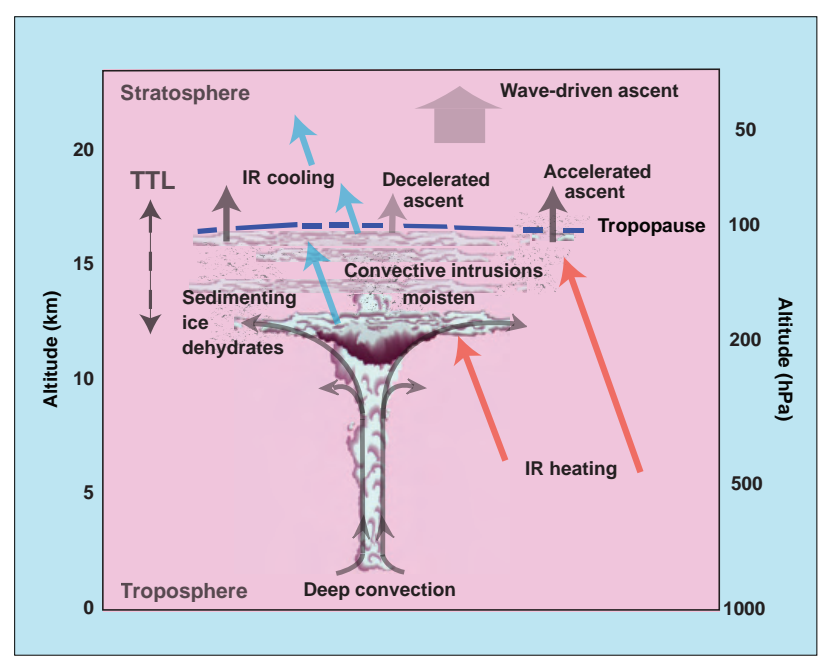

Fig. 14. Schematic of the processes involved in transport and dehydration of air that ascends from the troposphere into the stratosphere. The red arrows represent radiative heating, the blue arrows IR radiative cooling and the grey ones vertical transport.

large sizes to fall a large distance and leave the TTL. Since transport of the particles is both vertical and horizontal, the likelihood that they meet subsaturated conditions and evaporate within the TTL is relatively high.

\section{Conclusions}

The results of water vapor calculations for the period 19962005 with our atmospheric chemistry GCM have been shown to compare favorably with satellite measurements. The nudging technique applied, assimilating ECMWF meteorological analyses into the tropospheric part of the model domain, holds promise for simulations of stratospheric dynamics, and enables direct comparisons between measurement data and model results. Since the middle atmospheric part of the model domain above $200 \mathrm{hPa}$ is not nudged, the comparison provides evidence that TTL processes controlling water transport and stratospheric dehydration are well-represented.

The model successfully simulates characteristic features such as the SAO, the QBO and the tape recorder signal in water vapor, and the QBO phase evolution is close to observations (see also Jöckel et al., 2006). It appears that the SAO strongly influences the water vapor variability in the middle and upper stratosphere by modulating vertical transport processes. However, its influence on water vapor in the lower stratosphere is negligible. Furthermore, we obtain good agreement between modeled and satellite observed temperatures in the lower stratosphere and tropopause region.

This can be interpreted as verification of the model dynamics which govern adiabatic cooling, as well as diabatic processes such as IR radiative tendencies through clouds, water vapor and ozone. We furthermore compared model simulated with observed HALOE water vapor data, and the agreement appears to be generally good, i.e. in most of the stratosphere deviations are not significant and the average difference is small. Both the model results and HALOE satellite data indicate that very dry conditions, down to $\sim 1$ ppmv $\mathrm{H}_{2} \mathrm{O}$, can occur at $\sim 100 \mathrm{hPa}$, whereas at $\sim 70 \mathrm{hPa}$ mixing ratios generally exceed 2 ppmv owing to transport and mixing.

However, compared to HALOE our model tends to underrepresent the number of data points between 3 and 4 ppmv, leading to an overall model dry bias up to $0.5 \mathrm{ppmv}$. It should be noted, however, that differences in the vertical resolution between both data sets may contribute to discrepancies. For example, it cannot be excluded that the HALOE vertical averaging over a few kilometers at $100 \mathrm{hPa}$ includes a number of relatively moist tropospheric measurements. We recommend that satellite data are provided together with the averaging kernel applied in the retrieval algorithm, so that the model can be sampled similarly.

Though many aspects of stratospheric dehydration and transport across the tropical tropopause have been described previously, our atmospheric chemistry-GCM provides a new comprehensive view of the key processes involved. Within the troposphere in the inner-tropical convergence zone upward motion is driven by convection, whereas in the lower stratosphere upwelling is forced by large-scale wave dynamics, regionally modulated by net radiative heating or cooling. This has been schematically depicted in Fig. 14. Generally, mean vertical motion near the equatorial tropopause is slowly upward, but in some regions radiative cooling decelerates transport or even supersedes and causes subsidence. Our model predicts downward motion over the tropical Indian Ocean during NH summer. Hence the zonal mean vertical motion in the inner tropics is close to zero.

The regions of strongest upward transport in the lower stratosphere are located in the outer tropics, generally poleward from the most intense convection. This differs from the fountain concept by Newell and Gould-Stewart (1981), who assumed spatial coherence between convection over the maritime continent (Indonesia), low tropopause temperatures, associated dehydration and subsequent stratospheric entry in the same region during $\mathrm{NH}$ winter. Our model results suggest that upward motion at the tropopause is strongest over Southeast Asia in NH summer. Since the Southeast Asian monsoon convection is relatively deep, especially over the Tibetan Plateau, it moistens the lower stratosphere. Subsequently, this regional water vapor maximum ascends by radiative heating and is transported in the Tibetan High, which extends into the lower stratosphere, and fuels the moist phase of the tape recorder.

This seasonally varying stratospheric drying mechanism reconciles the distinct influences of deep convection and gradual dehydration within the TTL, as foreseen on the basis of water isotope ratio measurements (Webster and Heymsfield, 2002). In the TTL the air is desiccated over cold 
cumulonimbus anvils, the preferred location of thin cirrus. These clouds are formed within the TTL, gradually move upward with the wave driven ascent, and remove moisture by the sedimentation of ice particles. Thus, even though deeply penetrating cumulonimbus occasionally leave a water isotope signal, these overshooting clouds neither drive dehydration nor the large-scale motion.

As long as cumulonimbus anvils are present underneath the TTL, net radiative cooling decelerates upward motion and sustains saturation, so that sedimenting particles can escape the ascent. In the outflow regions where the anvils have dissipated, radiative heating takes over, upwelling increases and the residual moisture is carried into the stratosphere. Cirrus desiccation between 100 and $200 \mathrm{hPa}$ effectively diminishes the moisture flux by almost two orders of magnitude relative to the air mass flux. Air in the lower equatorial stratosphere is very dry, and the annual mean water mixing ratio is 2-2.5 ppmv. During NH summer the additional moisture supplied by deep Southeast Asian monsoon convection increases the stratospheric entry water mixing ratio between $30^{\circ} \mathrm{N}$ and $30^{\circ} \mathrm{S}$ to an annual mean of about 3-3.5 ppmv at $\sim 75 \mathrm{hPa}$.

Given that upward transport from the troposphere largely governs the water loading of the stratosphere, changes in TTL cirrus and ice particle sedimentation, and the moisture supply by monsoon convection can contribute to stratospheric humidity tendencies. HALOE measurements indicate a stratospheric drying episode between the years 2000 and 2002, while our model computes a more general drying tendency close to $0.5 \mathrm{ppmv} / \mathrm{dec}$ de since 1996 , most pronounced in the middle stratosphere. However, we emphasize the difficulty to discern a trend from variability, and longerterm studies will be needed for more definite conclusions.

Acknowledgements. We thank C. Kottmeier and H. Höller (project "Transport and Chemical Conversion in Convective Systems") for the use of graphics elements in Fig. 14, S. Borrmann for comments, and G. Stiller and M. Milz for providing MIPAS data. We acknowledge the European Union projects QUANTIFY and SCOUT-O3, and the German Research Foundation project CAWSES for support.

Edited by: M. Dameris

\section{References}

Alcala C. M. and Dessler A. E.: Observations of deep convection in the tropics using the Tropical Rainfall Measuring Mission (TRMM) precipitation radar, J. Geophys. Res., 107, 4792, doi:10.1029/2002JD002457, 2002.

Aumann, H. H., Broberg, S., Elliott, D., Gaiser, S., and Gregorich, D.: Three years of Atmospheric Infrared Sounder radiometric calibration validation using sea surface temperatures, J. Geophys. Res., D16S90, doi:10.1029/2005JD006822, 2006.

Bannister, R. N., O'Neil, A., Gregory, A. R., and Nissen, K. M.: The role of the south-east Asian monsoon and other seasonal fea- tures in creating the "tape-recorder" signal in the Unified Model, Q. J. R. Meteorol. Soc. 130, 1531-1554, 2004.

Bonazzola, M. and Haynes, P. H.: A trajectory-based study of the tropical tropopause region, J. Geophys. Res., 109, D20112, doi:10.1029/2003JD004356, 2004.

Brewer, A. W: Evidence for a world circulation provided by the measurements of helium and water vapour distribution in the stratosphere, Q. J. R. Meteorol. Soc. 75, 351-363, 1949.

Corti, T., Luo, B. P., Fu, Q., Vömel, H., and Peter, T.: The impact of cirrus clouds on troposphere-to-stratosphere transport, Atmos. Chem. Phys., 6, 2539-2547, 2006, http://www.atmos-chem-phys.net/6/2539/2006/.

Daley, R.: Atmospheric data analysis, Cambridge University Press, Cambridge, UK, 1991.

Danielsen, E. F.: A dehydration mechanism for the stratosphere, Geophys. Res. Lett., 9, 605-608, 1982.

Dessler, A. E., Palm, S. P., Hart, W. D., and Spinhirne J. D.: Tropopause-level thin cirrus coverage revealed by ICEsat/Geoscience Laser Altimeter System, J. Geophys. Res., 111, D08203, doi:10.1029/2005JD006586, 2006.

Divakarla, M. G., Barnet, C. D., Goldberg, M. D., McMillin, L. M., Maddy, E., Wolf, W., Zhou, L., and Liu, X.: Validation of Atmospheric Infrared Sounder temperature and water vapor retrievals with matched radiosonde measurements and forecasts, J. Geophys. Res., 111, D09S15, doi:10.1029/2005JD006116, 2006.

Eyring, V., Butchart, N., Waugh, D. W. et al.: Assessment of temperature, trace species and ozone in chemistry-climate model simulations in the recent past, J. Geophys. Res., 111, D22308, doi:10.1029/2006JD007327, 2006.

Fischer, H., and Oelhaf, H.: Remote sensing of vertical profiles of atmospheric trace constituents with MIPAS limb-emission spectrometers, Appl. Opt., 35, 2787-2796, 1996.

Folkins, I., Loewenstein, M., Podolske, J., Oltmans, S. J., and Proffitt, M.: A barrier to vertical mixing at $14 \mathrm{~km}$ in the tropics: Evidence from ozonesondes and aircraft measurements, J. Geophys. Res., 104, 22 095-22 102, 1999.

Fu, R., Hu, Y., Wright, J. S., Jiang, J. H., Dickinson, R. E., Chen, M., Filipiak, M., Read, W. G., Waters, J. W., and Wu, D. L.: Short circuit of water vapor and polluted air to the global stratosphere by convective transport over the Tibetan Plateau, Proc. Nat. Acad. Sci., 103, 5664-5669, 2006.

Fueglistaler, S., Wernli, H., and Peter, T.: Tropical troposphereto-stratosphere transport inferred from trajectory calculations, J. Geophys. Res., 109, D03108, doi:10.1029/2003JD004069, 2004.

Fueglistaler, S. and Haynes, P. H.: Control of interannual and longer-term variability of stratospheric water vapor, J. Geophys. Res., 110, D24108, doi:10.1029/2005JD006019, 2005.

Fueglistaler, S., Bonazzola, M., Haynes, P. H., and Peter, T.: Stratospheric water vapor predicted from the Lagrangian temperature history of air entering the stratosphere in the tropics, J. Geophys. Res., 110, D08107, doi:10.1029/2004JD005516, 2005.

Fueglistaler, S., and Fu, Q.: Impact of clouds on radiative heating rates in the lower tropical stratosphere, J. Geophys. Res., 111, D23202, doi:10.1029/2006JD007273, 2006.

Ganzeveld, L. N., van Aardenne, J., Butler, T., Lawrence, M. G., Metzger, S. M., Stier, P., Zimmerman, P., and Lelieveld, J.: Technical Note: Anthropogenic and natural offline emissions and the online EMissions and dry DEPosition (EMDEP) submodel of the 
Modular Earth Submodel System (MESSy), Atmos. Chem. Phys. Discuss., 6, 5457-5483, 2006,

http://www.atmos-chem-phys-discuss.net/6/5457/2006/.

Geller, M. A., Zhou, X., and Zhang, M.: Simulations of the interannual variability of stratospheric water vapor, J. Atmos. Sci., 59, 1076-1085, 2002.

Gettelman, A., Salby, M. L., and Sassi, F.: Distribution and influence of convection in the tropical tropopause region, J. Geophys. Res., 107, D10, 4080, doi:10.1029/2001JD001048 (2002).

Gettelman, A., Forster, P.M. de F., Fujiwara, M., Fu, Q., Vömel, H., Gohar, L. K., Johanson, C., and Ammerman, M: Radiation balance of the tropical tropopause layer, J. Geophys. Res., 109, D07103, doi:10.1029/2003JD004190, 2004a.

Gettelman, A., Weinstock, E. M., Fetzer, E. J., Irion, F. W., Eldering, A., Richard, E. C., Rosenlof, K. H., Thompson, T. L., Pittman, J. V., Webster, C. R., and Herman, R. L.: Validation of Aqua satellite data in the upper troposphere and lower stratosphere with in situ aircraft instruments, Geophys. Res. Lett., 31, L22107, doi:10.1029/2004GL020730, 2004b.

Gettelman, A., Collins, W. D., Fetzer, E. J., Eldering, A., Irion, F. W., Duffy, P. B., and Bala, G.: Climatology of uppertropospheric relative humidity from the Atmospheric Infrared Sounder and implications for climate, J. Climate, 19, 6104-6121, 2006 .

Gettelman, A., Fetzer, E. J., Eldering, A., and Irion, F. W.: The global distribution of supersaturation in the upper troposphere from the Atmospheric Infrared Sounder, J. Climate, 19, 60896103, 2006b.

Giorgetta, M. A. and Bengtsson, L.: Potential role of the quasibiennial oscillation in the stratosphere-troposphere exchange as found in water vapor in general circulation model experiments, J. Geophys. Res., 104, 6003-6019, 1999.

Giorgetta, M. A., Manzini, E., Roeckner, E., Esch, M., and Bengtsson, L.: Climatology and forcing of the quasi-biennial oscillation in the MAECHAM5 model, J. Climate, 19, 3882-3901, 2006.

Hagemann, S., Arpe, K., and Roeckner, E.: Evaluation of the hydrological cycle in the ECHAM5 model, J. Climate, 19, 3810-3827, 2006.

Harries, J. E., Russell III, J. M., Tuck, A. F., Gordley, L. L., Purcell, P., Stone, K. Bevilacqua, R. M., Gunson, M., Nedoluha, G., and Traub, W. A.: Validation of water vapor from the Halogen Occultation Experiment (HALOE), J. Geophys. Res., 101, 10 205-10 216, 1996.

Hartmann, D. L., Holton, J. R., and Fu, Q.: The heat balance of the tropical tropopause, cirrus, and stratospheric dehydration, Geophys. Res. Lett., 28, 1969-1972, 2001.

Haynes, P. H., Marks, C. J., McIntyre, M. E., Shepherd, T. G., and Shine, K. P.: On the "downward control" of extratropical diabatic circulations by eddy-induced zonal mean forces, J. Atmos. Sci., 48, 651-678, 1991.

Heymsfield, A. J. and Donner, L. J.: A scheme for parameterizing ice-cloud water content in general circulation models, J. Atmos. Sci., 47, 1865-1877, 1990.

Highwood, E. J. and Hoskins, B. J.: The tropical tropopause, Q. J. R. Meteorol. Soc., 124, 1579-1604, 1998.

Holton, J. R., Haynes, P. H., McIntyre, M. E., Douglas, A. R., Rood, R. R., and Pfister, L.: Stratosphere-troposphere exchange, Rev. Geophys., 33, 403-439, 1995.

Holton, J. R. and Gettelman, A.: Horizontal transport and the dehy- dration of the stratosphere, Geophys. Res. Lett., 28, 2799-2802, 2001.

Jackson, D. R., Burrage, M. D., Harries, J. E., Gray, L. J., and Russell III, J. M.: The semi-annual oscillation in upper stratospheric and mesospheric water vapour as observed by HALOE, Q. J. R. Meteorol. Soc., 124, 2493-2515, 1998.

Jensen, E. J., Pfister, L., Ackerman, A. S., Tabazadeh, A., and Toon, O. B.: A conceptual model of the dehydration of air due to freeze-drying by optically thin, laminar cirrus rising slowly across the tropical tropopause, J. Geophys. Res., 106, $17237-$ 17 252, doi:10.1029/2000JD900649, 2001.

Jensen, E., and Pfister, L.: Transport and freeze-drying in the tropical tropopause layer, J. Geophys. Res., 109, D02207, doi:10.1029/2003JD004022, 2004.

Jöckel, P., Sander, R., Kerkweg, A., Tost, H., and Lelieveld, J.: Technical Note: The Modular Earth Submodel System (MESSy) - a new approach towards Earth System Modeling, Atmos. Chem. Phys., 5, 433-444, 2005, http://www.atmos-chem-phys.net/5/433/2005/.

Jöckel, P., Tost, H., Pozzer, A., Brühl, C., Buchholz, J., Ganzeveld, L., Hoor, P., Kerkweg, A., Lawrence, M. G., Sander, R., Steil, B., Stiller, G., Tanarhte, M., Taraborelli, D., van Aardenne, J., and Lelieveld, J.: The atmospheric chemistry general circulation model ECHAM5/MESSy: Consistent simulation of ozone from the surface to the mesosphere, Atmos. Chem. Phys., 6, 50675104, 2006, http://www.atmos-chem-phys.net/6/5067/2006/.

Kerkweg, A., Sander, R., Tost, H., and P. Jöckel: Technical Note: Implementation of prescribed (OFFLEM), calculated (ONLEM), and pseudo-emissions (TNUDGE) of chemical species in the Modular Earth Submodel System (MESSy), Atmos. Chem. Phys., 6, 3603-3609, 2006a.

Kerkweg A., Buchholz, J., Ganzeveld, L., A. Pozzer, H. Tost, and P. Jöckel: Technical Note: An implementation of the dry removal processes DRY DEPosition and SEDImentation in, the Modular Earth Submodel System (MESSy), Atmos. Chem. Phys., 6, 4617-4632, 2006b.

Kley, D., Stone, E. J., Henderson, W. R., Drummond, J. W., Harrop, W. J., Schmeltekopf, L., Thompson, T. L., and Winkler, R. H.: In situ measurements of the mixing ratio of water vapor in the stratosphere, J. Atmos. Sci., 36, 2513-2524, 1979.

Kley, D., Russell III, J. M., and Phillips, C.: SPARC Assessment of upper tropospheric and stratospheric water vapour, WCRP-113, WMO/TD-No. 1043, SPARC Report No. 2, World Meteorological Organization, Geneva, 2000.

Landgraf, J. and Crutzen, P. J.:An efficient method for online calculations of photolysis and heating rates, J. Atmos. Sci., 55, 863878, 1998.

Lin, S. J., and Rood, R. B.: Multi-dimensional flux-form semiLagrangian transport schenes, Mon. Wea. Rev., 124, 2046-2070, 1996.

Lawrence, M. G. and Rasch, P. J.: Tracer transport in deep convective updrafts: plume ensemble versus bulk formulations, J. Atmos. Sci., 62, 2880-2894, 2005.

Lohmann, U. and Roeckner, E. : Design and performance of a new cloud microphysics parameterization developed for the ECHAM4 general circulation model, Clim. Dyn., 12, 557-572, 1996.

Lohmann, U., Roeckner, E., Collins, W. D. Heymsfield, A. J., McFarquhar, G. M., and Barnett, T. P.: The role of water va- 
por and convection during the Central Equatorial Pacific Experiment from observations and model simulations, J. Geophys. Res., 100(D12), 26 229-26246, 1995.

Luo, Z., and W. B. Rossow: Characterizing tropical cirrus life cycle, evolution and interaction with upper-tropospheric water vapor using Lagrangian trajectory analysis of satellite observations, J. Clim., 17, 4541-4563, 2004.

Majewski, D.: Balanced initial and boundary values for a limited area model, Beitr. Phys. Atm., 58, 147-165, 1985.

Manzini, E., Steil, B. Brühl, C., Giorgetta, M. A., and Krüger, K.: A new interactive chemistry-climate model: 2 . Sensitivity of the middle atmosphere to ozone depletion and increase in greenhouse gases and implications for recent stratospheric cooling. J. Geophys. Res., 108(D14), 4429, doi:10.1029/2002JD002977, 2003.

Manzini, E., Giorgetta, M. A., Esch, M., Kornblueh, L., and Roeckner, E.: The influence of sea surface temperatures on the northern winter stratosphere: ensemble simulations with the MAECHAM5 model, J. Climate, 19, 3863-3881, 2006.

Massie S., Gettelman, A., Randel, W., and Baumgardner, D.: Distribution of tropical cirrus in relation to convection, J. Geophys. Res., 107 (D21), 4591, doi:10.1029/2001JD001293, 2002.

McFarquhar, G. M., Heymsfield, A. J., Spinhirne, J., and Hart, B.: Thin and subvisual tropical tropopause cirrus, J. Atmos. Sci., 57, 1841-1853, 2000.

Mlynczak, M. G., Mertens, C. J., Garcia, R. R., and Portmann, R. W.: A detailed evaluation of the stratospheric heat budget 2 . Global radiation balance and diabatic circulations, J. Geophys. Res., 104, 6039-6066, 1999.

Mote, P. W., Rosenlof, K. H., McIntyre, M. E., Carr, E. S., Gille, J. C., Holton, J. R., Kinnersley, J. S., Pumphrey, H. C., Russell III, J. M., and Waters, J. W.: An atmospheric tape recorder: The imprint of tropical tropopasue temperatures on stratospheric water vapor, J. Geophys. Res., 101, 3989-4006, 1996.

Newell, R. E., and Gould-Stewart, S.: A stratospheric fountain?, J. Atmos. Sci. 38, 2789-2796, 1981.

Nordeng, T. E.: Extended versions of the convective parameterization scheme at ECMWF and their impact on the mean and transient activity of the model in the tropics, ECMWF Technical Report, 206, Reading, UK, 1994.

Norton, W. A.: Longwave heating of the tropical lower stratosphere, Geophys. Res. Lett., 28, 3653-3656, 2001.

Peter, T. Luo, B. P., Wirth, M, Kiemle, C., Flentje, H., Yushkov, V. A., Khattatov, V., Rudakov, V., Thomas, A., Borrmann, S., Toci, G., Mazzinghi, P., Beuermann, J., Schiller, C., Cairo, F, Di Donfrancesco, G., Adriani, A., Volk, C. M., Ström, J., Noone, K., Mitev, V., MacKenzie, R. A., Carslaw, K. S., Trautmann, T., Santacesaria, V., and Stefanutti, L.: Ultrathin Tropical Tropopause Clouds (UTTCs): I. Cloud morphology and occurrence, Atmos. Chem. Phys., 3, 1083-1091, 2003, http://www.atmos-chem-phys.net/3/1083/2003/.

Plumb, R. A. and Eluszkiewiwicz, J.: The Brewer-Dobson circulation: dynamics of the tropical upwelling, J. Atmos. Sci., 56, 868-890, 1999.

Potter, B. E. and Holton, J. R.: The role of monsoon convection in the dehydration of the lower tropical stratosphere, J. Atmos. Sci., 52, 1034-1050, 1995.

Randel, W. J. and Wu, F.: Isolation of the ozone QBO in SAGE II data by singular-value decomposition, J. Atmos. Sci., 53, 2546-
2559, 1996.

Randel, W. J., Zawodny, J. M., and Oltmans, S. J. : Seasonal variation of water vapor in the lower stratosphere observed in Halogen Occultation Experiment data, J. Geophys. Res., 106(D13), 14313-14 326, doi:10.1029/2001JD900048, 2001.

Randel, W. J., Wu, F., Oltmans, S. J., Rosenlof, K., and Nedoluha G. E.: Interannual changes of stratospheric water vapor and correlations with tropical tropopause temperatures, J. Atmos. Sci., 61, 2133-2148, 2004.

Randel, W. J., Wu, F., Vömel, H., Nedoluha, G. E., and Forster, P.: Decreases in stratsopheric water vapor after 2001: Links to changes in the tropical tropopause and the Brewer-Dobson circulation, J. Geophys. Res., 111, D12312, doi:10.1029/2005JD0006744, 2006.

Reithmeier, C. and Sausen, R.: ATTILA - Atmospheric Tracer Transport in a Lagrangian model, Tellus, 54, 278-299, 2002.

Remsberg, E. E., Bhatt, P. P., and Russell III, J. M.: Estimates of the water vapor budget of the stratosphere from UARS HALOE data, J. Geophys. Res., 101(D3), 6749-6766, 1996.

Roeckner, E., Bäuml, G., Bonaventura, L., Brokopf, R., Esch, M., Giorgetta, M., Hagemann, S., Kirchner, I., Kornblueh, L., Manzini, E., Rhodin, A., Schlese, U., Schulzweida, U., and Tompkins, A.: The atmospheric general circulation model ECHAM5. PART I: Model description, Max Planck Institute for Meteorology, MPI-Report 349,

http://www.mpimet.mpg.de/fileadmin/publikationen/Reports/ maxscirep349.pdf, 2003.

Roeckner, E., Brokopf, R., Esch, M., Giorgetta, M., Hagemann, S., Kornblüh, Manzini, L. E., Schlese, U., and Schulzweida, U.: Sensitivity of simulated climate to horizontal and vertical resolution in the ECHAM5 atmosphere model, J. Climate, 19, 37713791, 2006.

Rosenlof, K. H., and Holton, J. R.: Estimates of the stratospheric residual circulation using the downward control principle, J. Geophys. Res., 98, 10 465-10 479, 1993.

Rosenlof, K. H.: Seasonal cycle of the residual mean meridional circulation in the stratosphere, J. Geophys. Res., 100, 5173-5191, 1995.

Russell, J. M. III, Gordley, L. L., Park, J. H., Drayson, S. R., Hesketh, W. D., Cicerone, R. J. Tuck, A. F., Frederick, J. E., Harries, J. E., and Crutzen, P. J.: The Halogen Occultation Experiment, J. Geophys. Res., 98, 10777-10 798, 1993.

Sander, R., Kerkweg, A., Jöckel, P., and Lelieveld, J.: Technical Note: The new comprehensive atmospheric chemistry module MECCA, Atmos. Chem. Phys., 5, 445-450, 2005, http://www.atmos-chem-phys.net/5/445/2005/.

Sandu, A. and Sander, R.: Technical Note: Simulating chemical systems in Fortran90 and Matlab with the 5 kinetic preprocessor KPP-2.1, Atmos. Chem. Phys., 6, 187-195, 2006, http://www.atmos-chem-phys.net/6/187/2006/.

Seidel, D. J., Ross, R. J., Angell, J. K., and Reid, G. C.: Climatological characteristics of the tropical tropopause as revealed by radiosondes, J. Geophys. Res., 106, 7857-7878, 2001.

Sherwood, S. C.: A stratospheric "drain" over the maritime continent, Geophys. Res. Lett., 27, 677-680, 2000.

Sherwood, S. C., and A. E. Dessler: A model for transport across the tropical tropopause, J. Atmos. Sci., 58, 765-779, 2001.

Soden, B. J.: The impact of tropical convection and cirrus on upper tropospheric humidity: A Lagrangian analysis 
of satellite measurements, Geophys. Res. Lett., 31, L20104, doi:10.1029/2004GL020980, 2004.

Solomon, S.: Stratospheric ozone depletion: A review of concepts and history, Rev. Geophys., 37, 275-316, 1999.

Sparling, L. C.: Statistical perspectives on stratospheric transport, Rev. Geophys., 38, 417-436, 2000.

Steil, B., Brühl, C., Manzini, E., Crutzen, P., Lelieveld, J., Rasch, P. J., Roeckner, E., and Krüger, K.: A new interactive chemistry climate model. I: Present day climatology and interannual variability of the middle atmosphere using the model and 9 years of HALOE/UARS data, J. Geophys. Res., 108, 4290, doi:10.1029/2002JD002971, 2003.

Stohl, A. and Trickl, T. : A textbook example of long-range transport: Simultaneous observation of ozone maxima of stratospheric and North American origin in the free troposphere over Europe, J. Geophys. Res., 104(D23), 30 445-30 462, 1999.

Thomas, A., Borrmann, S., Kiemle, C., Cairo, F., Volk, M., Beuermann, J., Lepuchov, B., Santacesaria, V., Matthey, R., Rudakov, V., Yushkov, V., MacKenzie, R. A., and Stefanutti, L.: In situ measurements of background aerosol and subvisible cirrus in the tropical tropopause region, J. Geophys. Res., 107 (D24), 4763, doi:10.1029/2001JD001385, 2002.

Tiedtke, M.: A comprehensive mass flux scheme for cumulus parametrization in large-scale models, Mon. Weather Rev., 117, 1779-1800, 1989.

Tost, H.: Global Modelling of Cloud, Convection and Precipitation Influences on Trace Gases and Aerosols, Ph.D. thesis, University of Bonn, Germany, 2006.

Tost, H., Jöckel, P., Kerkweg, A., Sander, R., and Lelieveld, J.: Technical Note: A new comprehensive SCAVenging submodel for global atmospheric chemistry modelling, Atmos. Chem. Phys., 6, 565-574, 2006a.

Tost, H., Jöckel, P., and Lelieveld, J.: Influence of different convection parameterisations in a GCM, Atmos. Chem. Phys., 6, 54755493, 2006b.

Traub, M. A.: Lagrangian transport evaluation of atmospheric chemistry in the Mediterranean region Ph.D. Thesis, University of Mainz, Germany, 2004.

Tuck A. F., Baumgardner, D., Chan, K. R., Dye, J. E., et al.: The Brewer-Dobson circulation in the light of high altitude in situ aircraft observations, Q. J. R. Meteorol. Soc., 123, 1-69, 1997.
Van Aalst, M. K., van den Broek, M. M. P., Bregman, A., Brühl, C., Steil, B., Toon, G. C. Garcelon, S., Hansford, G. M., Jones, R. L., Gardiner, T. D., Roelofs, G. J., Lelieveld, J., and Crutzen, P. J.: Trace gas transport in the 1999/2000 Actic winter: comparison of nudged GCM runs with observations, Atmos. Chem. Phys., 4, 81-93, 2004, http://www.atmos-chem-phys.net/4/81/2004/.

Volk, C. M., Elkins, J. W., Fahey, D. W., Salawitch, R. J., Dutton, G. S., Gilligan, J. M., Proffitt, M. H., Loewenstein, M., Podolske, J. R., Minschwaner, K., Margitan, J. J., and Chan, K. R.: Quantifying transport between the tropical and mid-latutude lower stratosphere, Science, 272, 1763-1768, 1996.

Vömel, H., Oltmans, S. J., Johnson, B. J., Hasebe, F., Shiotani, M., Fujiwara, M., Nishi, N., Agama, M., Cornejo, J., Paredes, F., and Enriques, H.: Balloon-borne observation of water vapor and ozone in the tropical upper troposphere and lower stratosphere, J. Geophys. Res., 107, 4210, doi:10.1029/2001JD000707, 2002.

Wang, D. Y., von Clarmann, T., Fischer, H., Funke, B., et al.: Validation of stratospheric temperatures measured by Michelson Interferometer for Passive Atmospheric Sounding (MIPAS) on Envisat, J. Geophys. Res., 110, D08301, doi:10.1029/2004JD005342, 2005.

Webster, C. R. and Heymsfield, A. J.: Water isotope ratios D/H, ${ }^{18} \mathrm{O} /{ }^{16} \mathrm{O},{ }^{17} \mathrm{O} /{ }^{16} \mathrm{O}$ in and out of clouds map dehydration pathways, Science, 302, 1742-1692, 2003.

Wernli H., and Bourqui, M.: A Lagrangian "1-year climatology" of (deep) cross-tropopause exchange in the extratropical Northern Hemisphere, J. Geophys. Res., 107 (D2), 4021, doi:10.1029/2001JD000812, 2002.

Wild, M. and Roeckner, E.: Radiative fluxes in the ECHAM5 general circulation model, J. Climate, 19, 3792-3809, 2006.

Wylie, D. P., and Wang P.-H.: Comparison of cloud frequency data from the high-resolution infrared radiometer sounder and the Stratospheric Aerosol and Gas Experiment II, J. Geophys. Res., 102, 29 893-29 900, 1997.

Yulaeva, E., Holton, J. R., and Wallace, J. M.: On the cause of the annual cycle in tropical lower stratospheric temperatures, J. Atmos. Sci., 51, 169-174, 1994. 